\title{
Effectiveness the Theory-Based Intervention Based on Health Belief Model on Health Promotion Lifestyle in Individuals Susceptible to Cardiovascular Diseases
}

\begin{abstract}
Background and Objective: Cardiovascular diseases are a main reason of disability and death around the world. Evidence suggests that many social and individualbased health-related factors are changeable and modifiable. The aim of this study was to evaluate the effect of a theory-based intervention based on the health belief model on health-promoting lifestyle behaviors in individuals susceptible to cardiovascular diseases.

Materials and Methods: In this quasi-experiment, we recruited 180 individuals having at least two risk factors out of five cardiovascular risk factors, including smoking, diabetes, hypertension, high cholesterol, and obesity. Data were gathered in three phases (before, immediately after, and five months after implementing the intervention) using the health-promoting lifestyle questionnaire (HPLQ), general health questionnaire (GHQ), and a designed questionnaire to measure the health belief model constructs. The intervention included five training sessions based on the health belief model. Data were analyzed using the statistical tests in the SPSS. Results: Findings showed that the theory-based educational intervention was effective in improving some domains of lifestyle, including nutrition, physical activity, interpersonal relationships, stress management and health accountability. Also, the mean blood pressure and the mean tobacco use showed a significant decrease in the intervention group after the intervention. Educational intervention also led to improvements in health belief model constructs including perceived susceptibility, perceived severity and perceived benefits $(P<0.001)$.

Conclusion: Intervention based on an individual-based health behavior change model resulted in improving some lifestyle dimensions, model's constructs and clinical outcomes. In order to provide wider and sustained changes, using ecologic models of behavior change including inter-personal, organizational and communitybased models are suggested.

Keywords: Cardiovascular Disease, Healthy Lifestyle, Health Belief Model Paper Type: Research Article.
\end{abstract}

Citation (Vancouver): Babaei S, Shakibazade E, Shojaeizadeh D, Yaseri M, Mohammadzade A. Effectiveness the Theory-Based Intervention Based on Health Belief Model on Health Promotion Lifestyle in Individuals Susceptible to Cardiovascular Diseases. Iran J Health Educ Health Promot. Spring 2020;8(3): 224-239. [Persian]x

- Citation (APA): Babaei S., Shakibazade E., Shojaeizadeh D., Yaseri M., Mohammadzade A. Effectiveness the Theory-Based Intervention Based on Health Belief Model on Health Promotion Lifestyle in Individuals Susceptible to Cardiovascular Diseases. Iranian Journal of Health Education \& Health Promotion., 8(3), 224-239 . [Persian]
Sohrab Babaei

MSc, Department of Health Education and Health Promotion, Tehran university of medical science, Tehran, Iran.

Elham Shakibazade

Associate Professor, Department of Health Education and Health Promotion, Tehran university of medical science, Tehran, Iran. (corresponding author) Email: shakibazadeh@sina.tums.ac.ir

Davod Shojaeizadeh

Professor, Department of Health Education and Health Promotion, Tehran university of medical science, Tehran, Iran.

Mehdi Yaseri Associate Professor, Department of Biostatistics, Tehran university of medical science, Tehran, Iran.

Alireza Mohammadzade MD, Taslihat Health Center, Tehran, Iran.

Received: 2019/11/3

Accepted: 2019/12/21

Doi: 10.29252/ijhehp.8.3.224 
ارزشيابى تاثير مداخله آموزشى مبتنى بر الكوى اعتقاد بهداشتى بر رفتارهاى ارتقادهنده

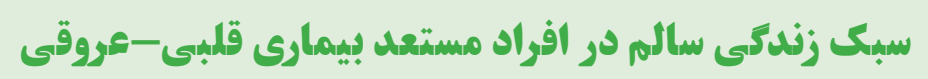

سهر اب بابائى دانشجوى كارشناسى ارشد، آموزش بهداشت و ارتقاى

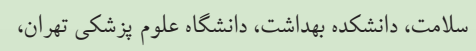
تهران، ايران الهام شكيباز اده

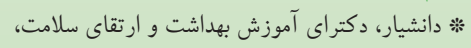

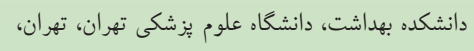
ايران(نويسنده مسئول) Email: shakibazadeh@sina.tums.ac.ir داوود شجاعى زاده استاد، دكتراى آموزش بهاعداشت و و ارتقاى سلامت، دانشكاء علوم يز شكى و خدمات بهداشتى تهران، تهران،

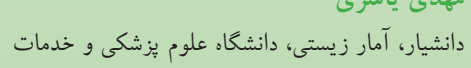

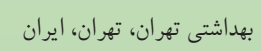

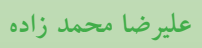
يزشك عمومى، پِايحاء سلامت تسليحات، تهران، ايران تاريخ د ريافت: ץ |

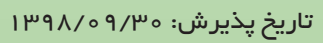

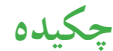

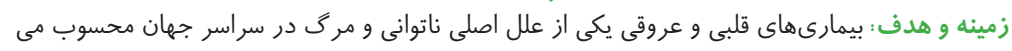

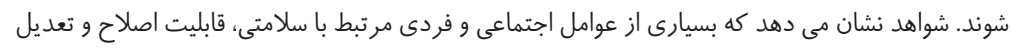

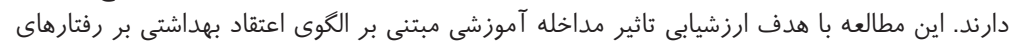

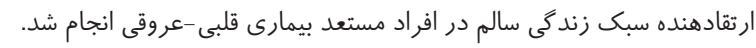

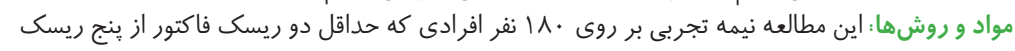

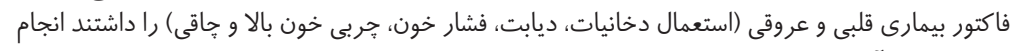

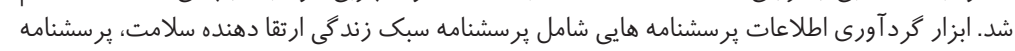

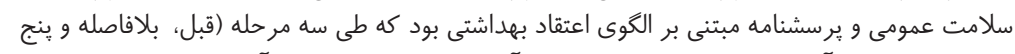

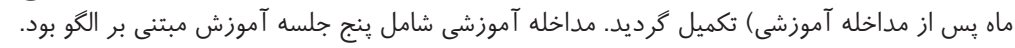

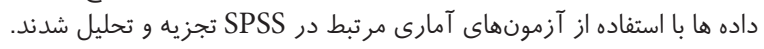

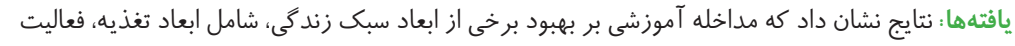

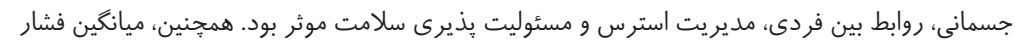

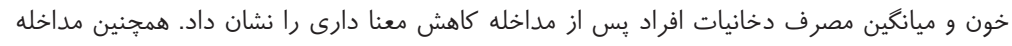

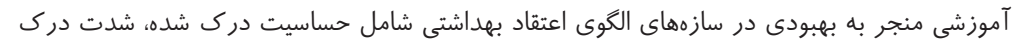

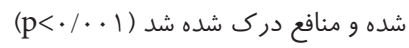

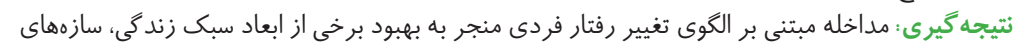

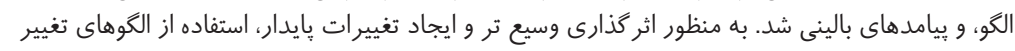

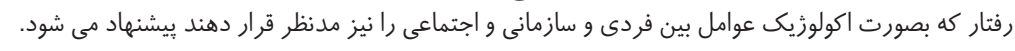

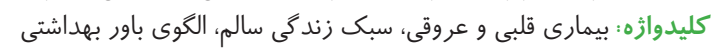

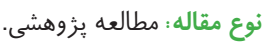

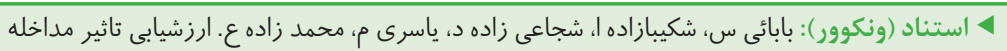

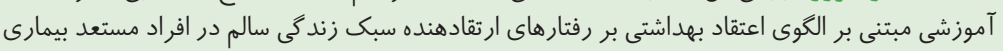

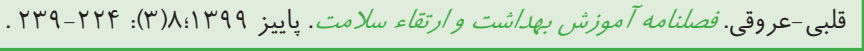

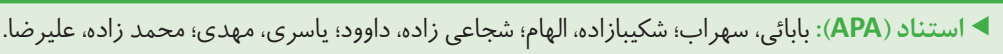

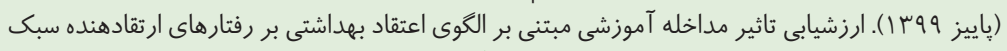

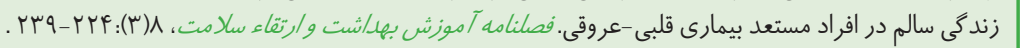


اين بيمارى ها مى شود. در حال حاضر، تكيه عمده بر فراهم كردن

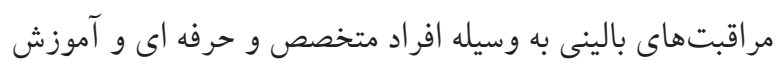

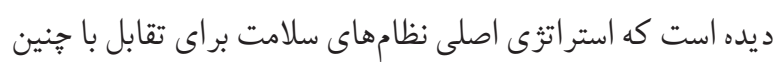

$$
\text { شرايطى است (V). }
$$

مهارتهاى فردى يكى از فاكتورهاى انتخاب شيوه زندكى

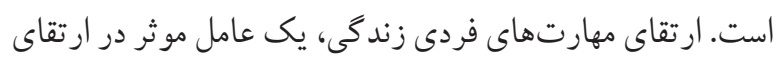

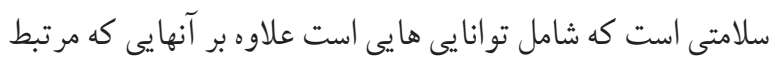

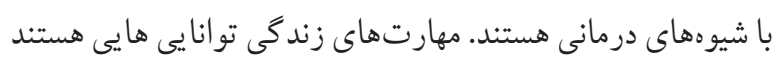

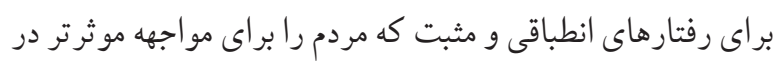

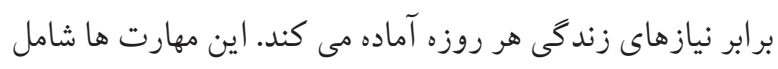
مهارتهاى فردى، ميان فردى، شناختى و جسمى است كه بردي باعث

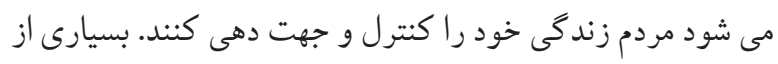

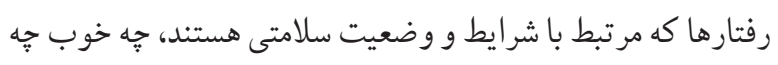

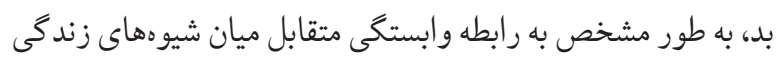

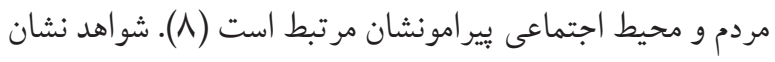

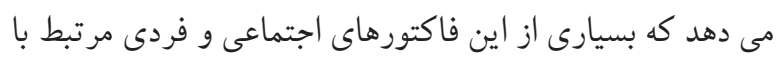

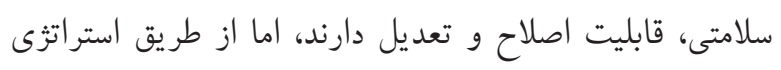

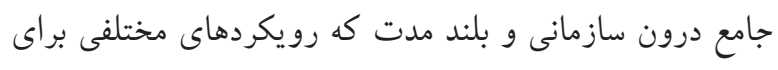

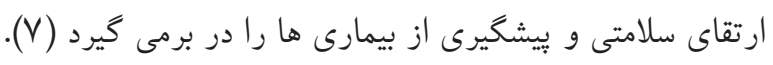

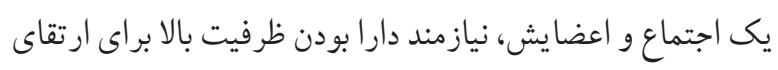

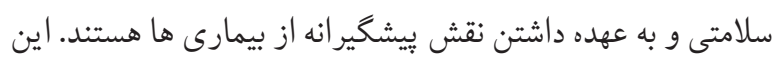

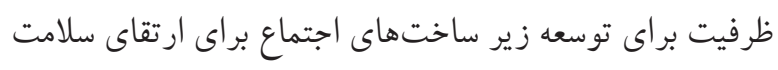

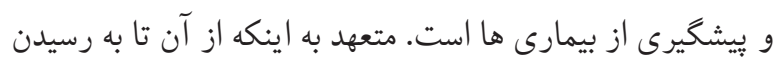

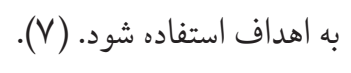

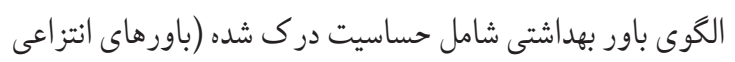

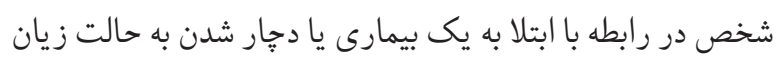

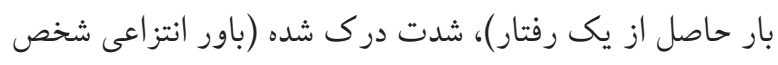

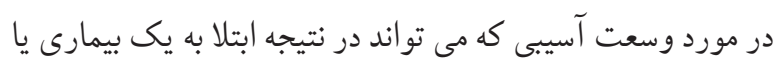

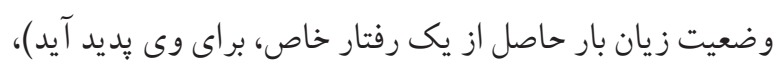

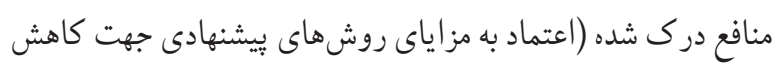

يكى از مشكلات بزرك سلامت در دنيا بيمارى هاى قلبى و عروقى

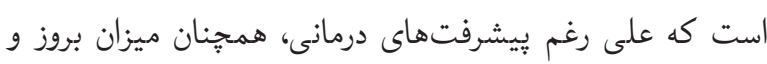

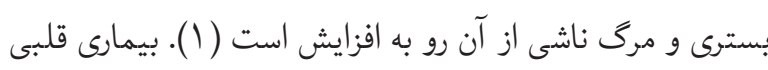

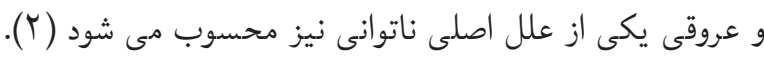

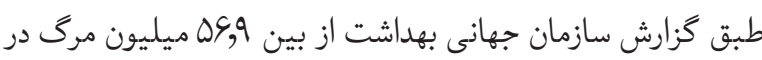

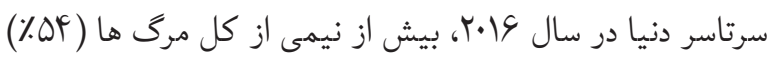

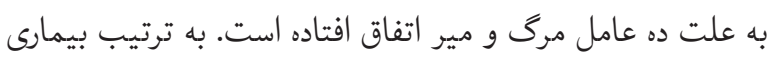

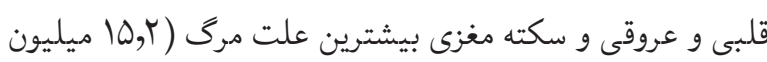

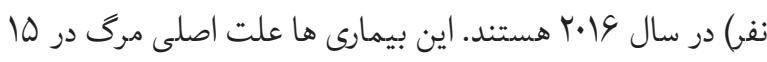

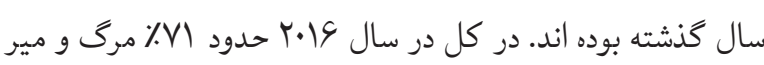

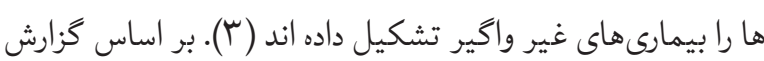

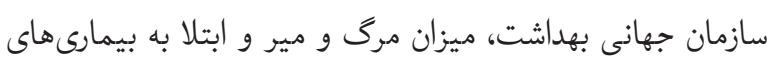

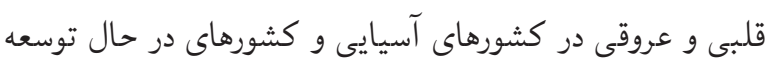

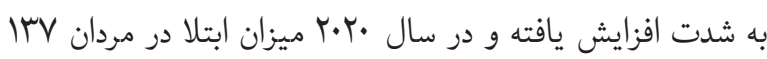
درصد و در زنان • آ درصد افزايش خواهد يافت.

مهم ترين عوامل خطرزاى بيمارى قلبى و عروقى كه مستقل از

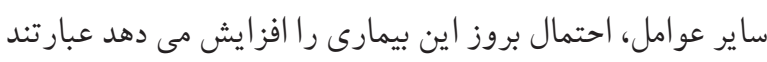

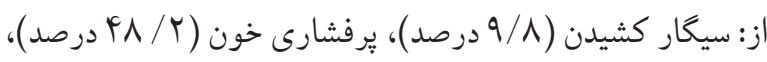

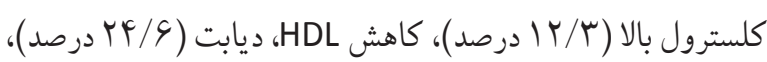

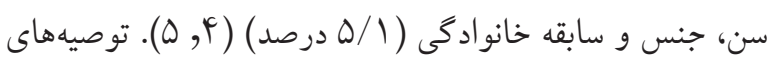

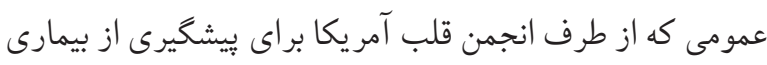

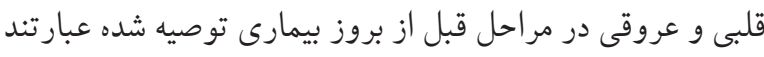

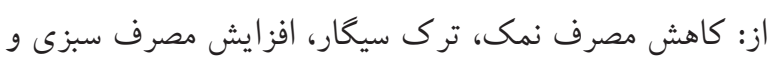

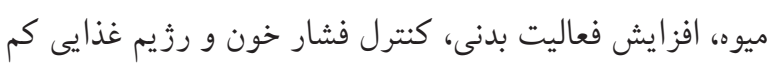

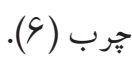
بيمارى هاى مزمن يرهز ينه مى باشند و اين مقوله نيازمند منابع

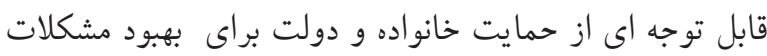

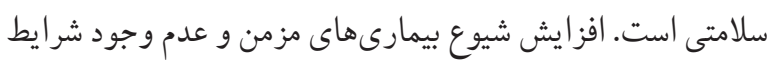

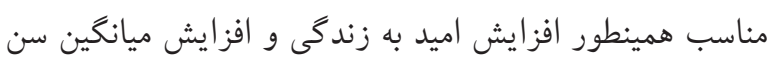

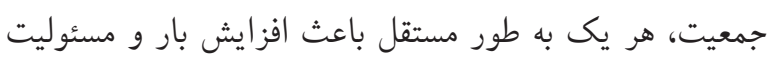


نفر كه دو گروه آزمون ( •9 نفر) و كنترل ( •9 نفر) تقسيم كرديم

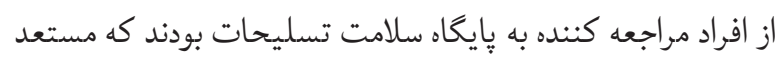

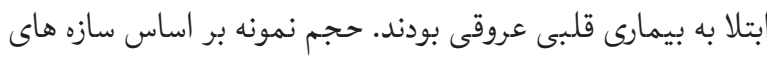

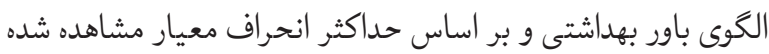

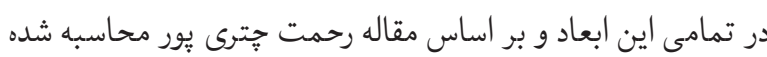

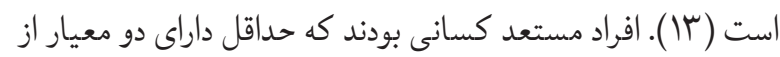
ينج ريسك فاكتور تعيين شده براى بيمارى قلبى و عروقى (استعمال

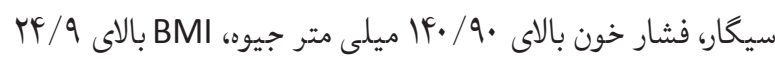

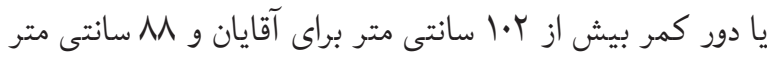

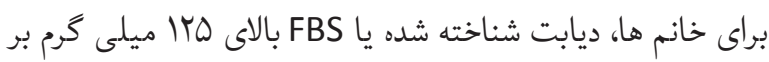

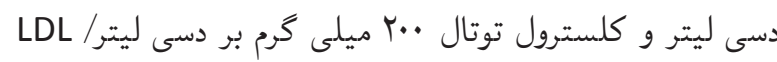

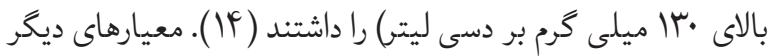
عبارت بودند از داشتن حداقل سواد خواندن و نوشتن، گروه سنى بين

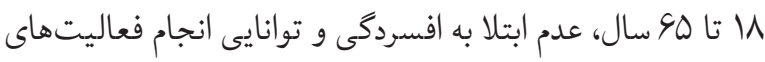

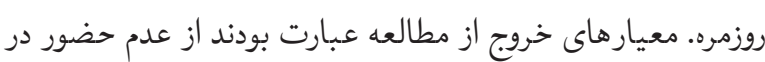

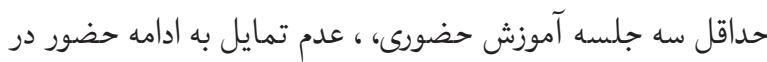

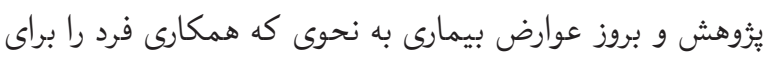
ادامه شركت در يُوهش مشكل سازد.

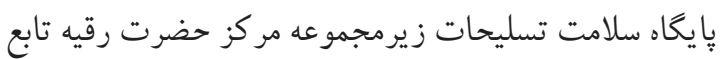
ستاد بهداشت و درمان شمال دانشخاه علوم يزشكى شهيد بهشتى است كه شامل ده هزار نفر جمعيت تحت يوشش مى باشد. خدمات

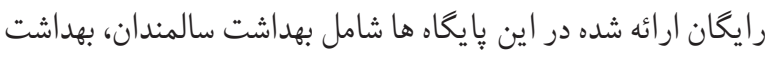

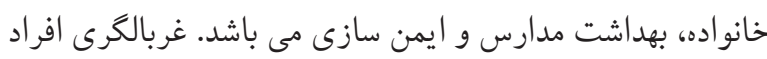
مستعد بيمارى قلبى و عروقى براى اولين بار تحت عنوان اين

$$
\text { بثوهش در اين پايكاه صورت كرفت. }
$$

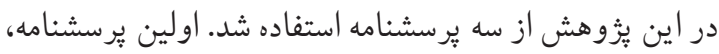

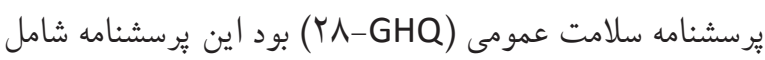

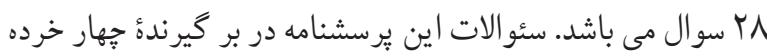
مقياس مى باشد كه هر يك از آنها خود شامل V سئوال مى باشند.

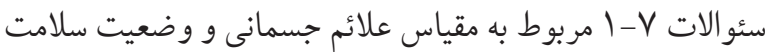

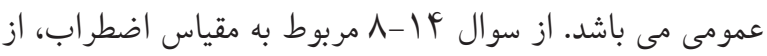

خطر يا وخامت بيمارى يا وضعيت زيان بار حاصل از يك رفتار

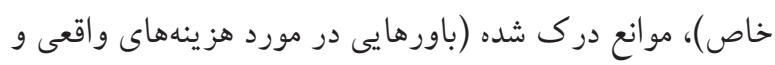
متصور بييخيرى رفتار جديد)، راهنمايى براى عمل (نيروهاى تسريع كننده اى كه موجب احساس نياز شخص به انجام عمل مى گر دد.)،

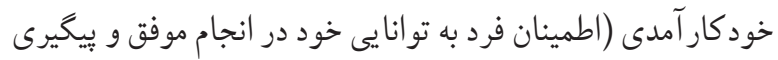
يك رفتار) مى باشند (9). مطالعات نشان داده است كه مداخلات

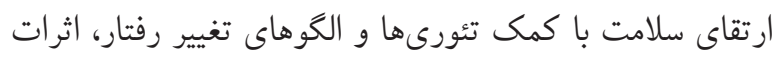

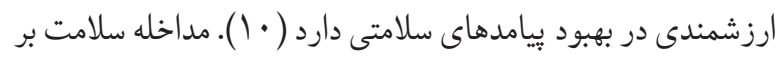

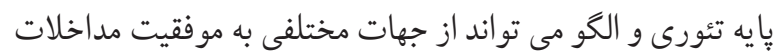
ارتقاى سلامت كمك كند: إ- منجر به تدوين اهداف قابل اندازه

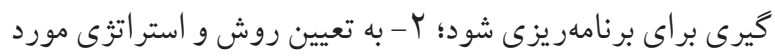

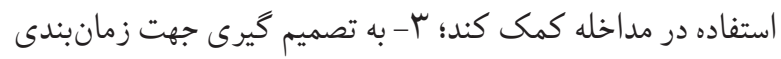

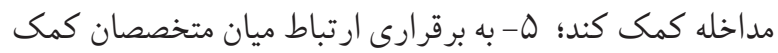
كند؛ و 9- به تكرار و بازسازى برنامه كمك كند ( • (1).

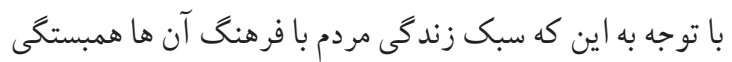

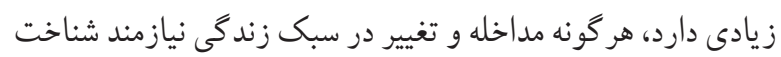

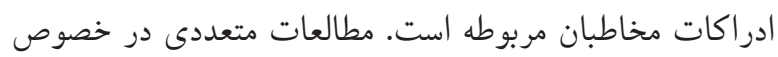
تعيين همبستكى بين سازهایى الكوى باور تندرستى با رفتارهاى

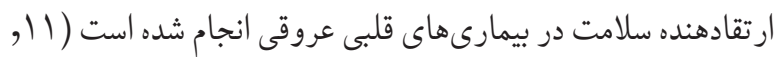

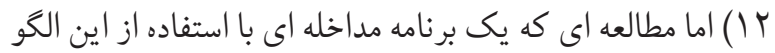
براى بهبود سبك زندگى افراد مستعد بيمارى قلبى عروقى اجرا و ارزشيابى كند در دسترس نبود. با توجه به اين موضوع، ما در

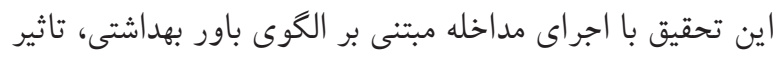

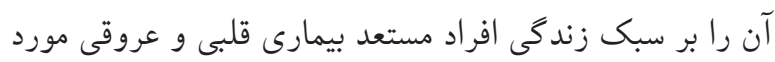
ارزشيابى قرار داديم. - مان

$$
\text { روش كار }
$$

اين يك مطالعه نيمه تجربى شاهددار تصادفى در دو گروه آزمون

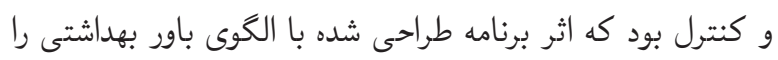

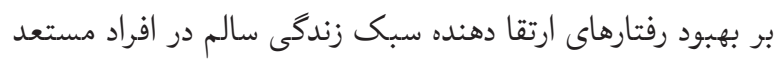

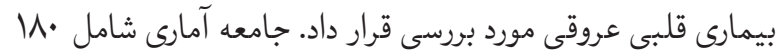


F T نمره از آن ميتواند كسب شود)؛ و بعد تغذيه (شامل 9 سوال است و سو الات به ترتيب سوالات مى باشد. حداقل نمره اين بخش صفر و حداكثر نمره كسب شده

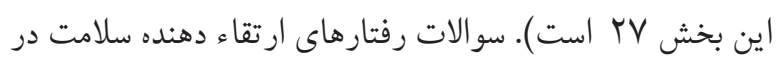

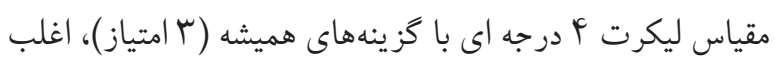

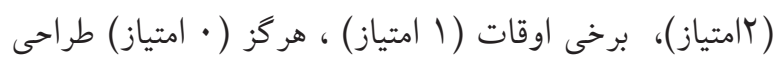

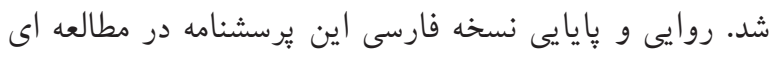

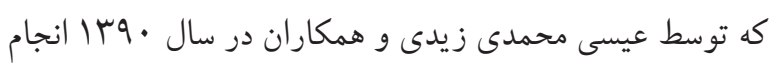

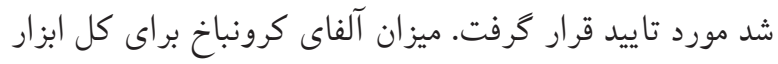

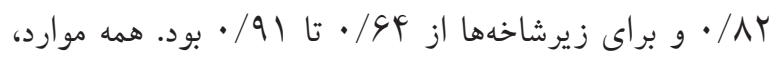

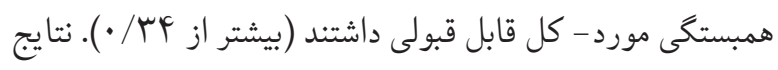

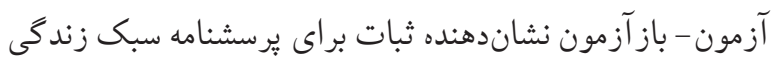

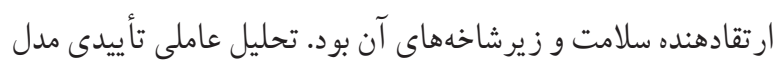

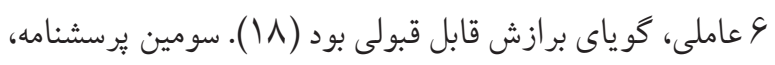

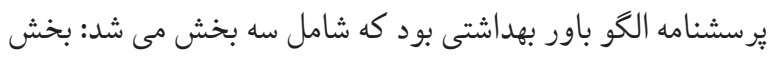

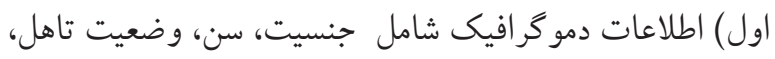

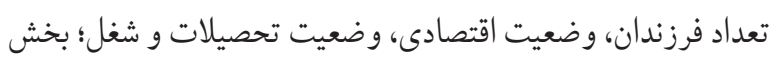
دوم) سو الات مربوط به سازههاى الخو باور بهداشتى شامل سو الات ونديك

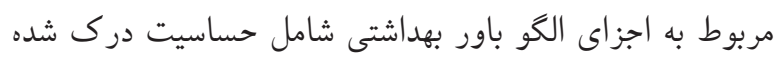

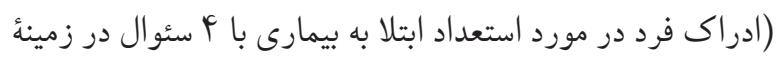
خطر كاهش سن ابتلا به بيمارى، احتمال خطر در فرد و خطرات

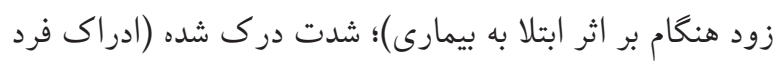

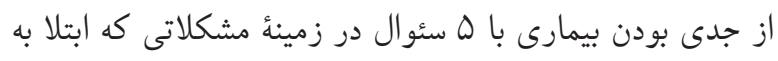

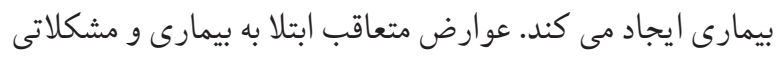

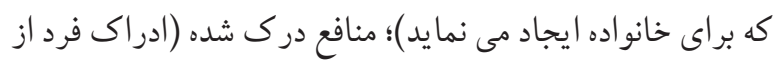

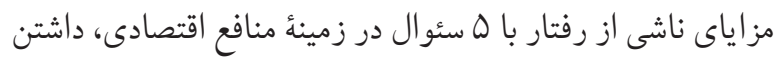

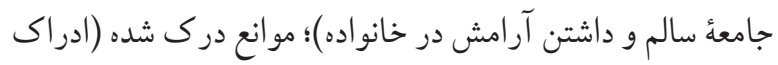

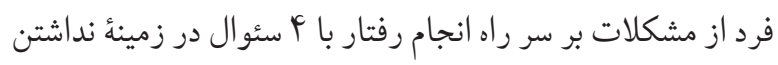

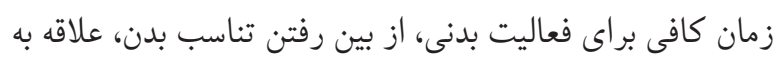

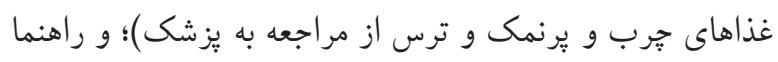
براى عمل (محر كهاى سرعت بخش انجام رفتار يك سئو ال) بود.)؛
سئوال ها تا ال مربوط به مقياس اختلال عملكرد اجتماعى، و

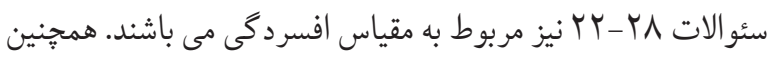
جهت نمره كذارى اين يرسشنامه از روش ليكرت استفاده شد كه به برس

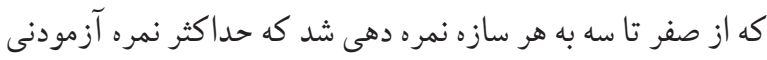

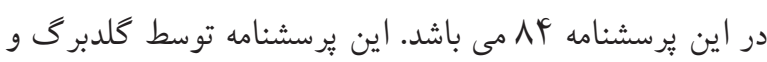

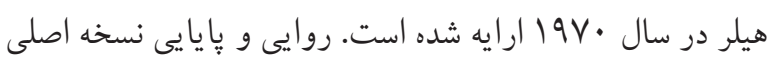

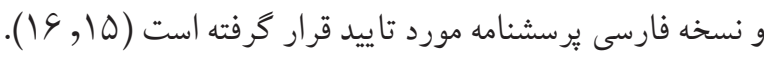

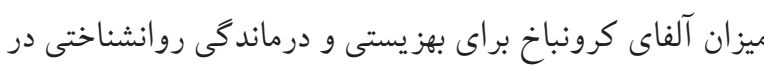

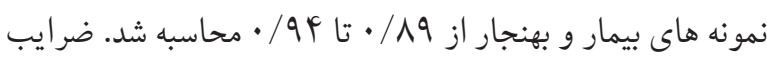

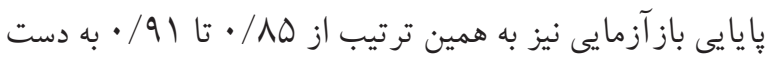

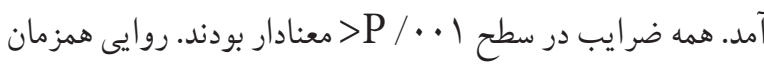
مقياس سلامت روانى بر حسب ضرايب همبستكى زير مقياس هاى

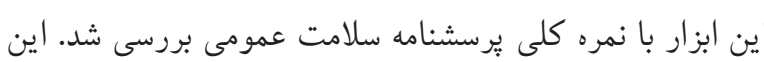

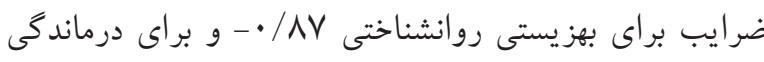

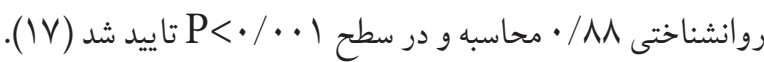
دومين بر سشنامه، يرسشنامه سبك زندگى ارتقا دهنده سلامت مى رو

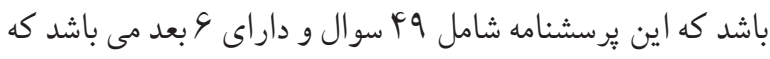

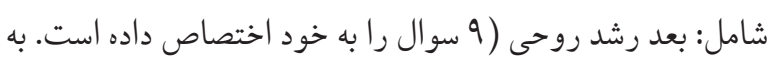

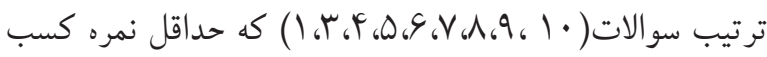
شده اين بخش صفر و حداكثر نمره كسب شده YV امتياز مى باشد)؛ بعد مسئوليت يذيرى سلامت (^ سوال را به خود اختصاص داده است. شامل سوالات · • حداقل نمره كسب شده در اين بعد صفر و حداكثر نمره آن MF

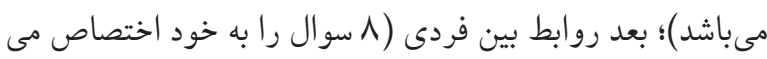

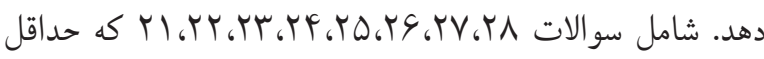
نمره كسب شده در اين بخش صفر و حداكثر آن MF مى باشد)؛ بعد مديريت استرس V) سوال را به خود اختصاص مى لمهد، به ترتيب

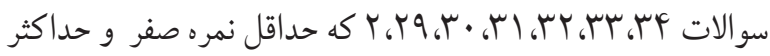

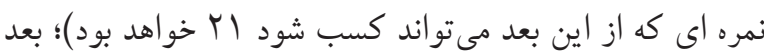

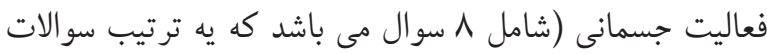

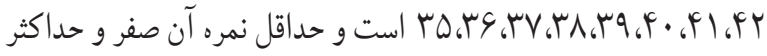


مداخله آموزشى در قسمت مداخله آموزشى، مطالب بر اساس سازهاى الخو باور

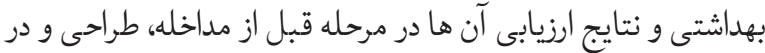

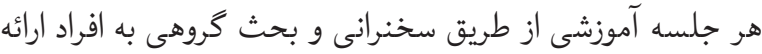

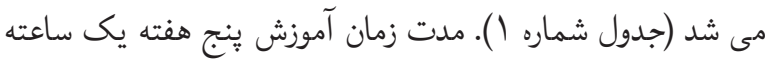

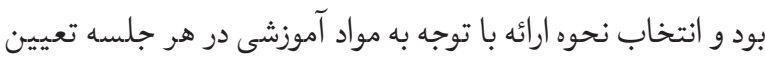

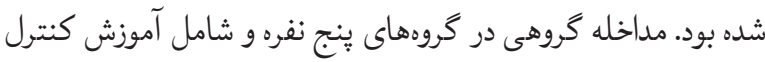
فشارخون، قند خون، جربى خون، و رفتارهاى ارتقادهنده سلامت درد درد

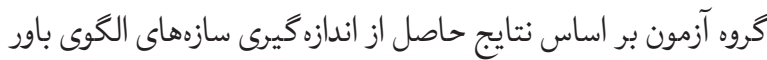
بهداشتى انجام شد. همجنين در هر جلسه آموزش، افراد شركت كننده از نظر بالينى (ميزان فشار خون، تعداد ضربان قلب، ميزان اكسيثن

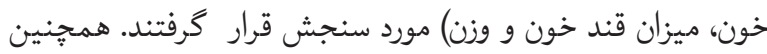

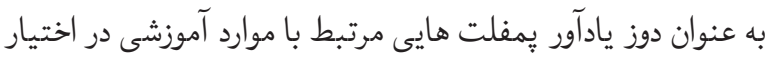

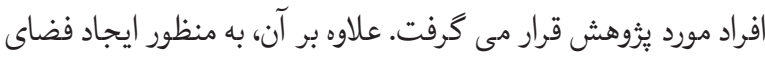
انكيزشى آموزشى براى افراد، رباتى در إيليكيشن تلكرام ايجاد كرديم

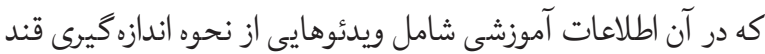

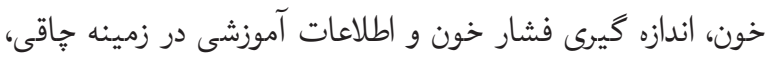
ديابت، عوامل خطرساز بيمارى قلبى و عروقى و سبك زندگى سالم ارائه شد. همجنين در جهت تسهيل جمع آورى ثرسشنامه، سوالات

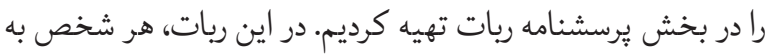

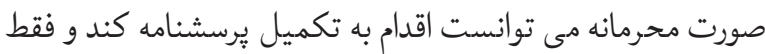

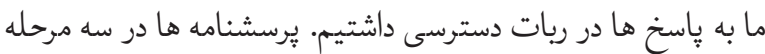

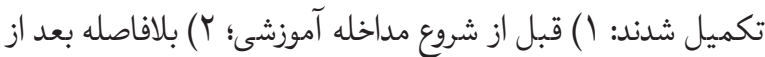

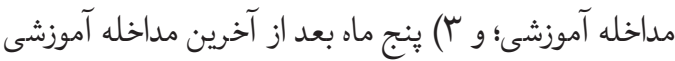
ملاحظات اخلاقى ملك به منظور اجراى اين مطالعه، اطلاعات صحيح به شركت كنندگان در

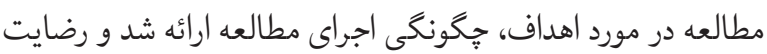
آكاهانه افراد براى شركت در مطالعه جلب شد. در ضمن درد مرده مورد محرمانه بودن اطلاعات شركت كنندگان در تمامى مراحل مطالعه به آن ها اطمينان داده شد. اصل سودمندى، عدالت و استقلال درد مشاركت كنندگان در مطالعه رعايت شد.
بخش سوم، شامل ه سؤال در زمينهُ رفتارهاى يبشكيرى كننده از

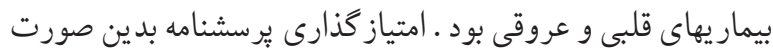

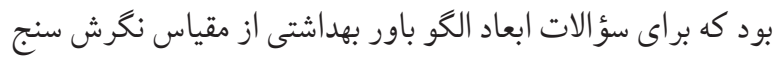

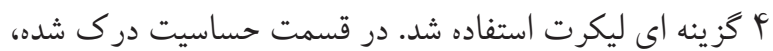
شدت درك شده و منافع درك شده به كزينهاى كاملاً

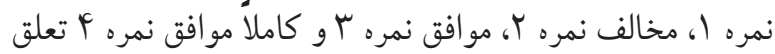

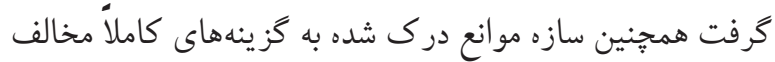

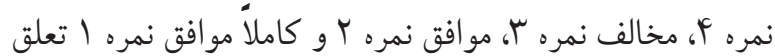
كرفت ـ در مورد سئو الات رفتارهاى ييشخيرى كننده از بيمار يهاى

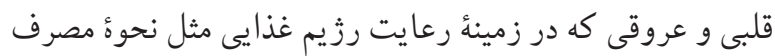

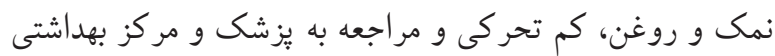

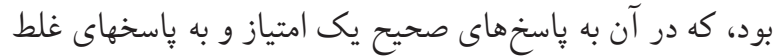

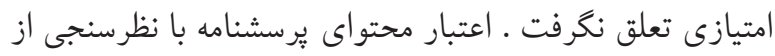

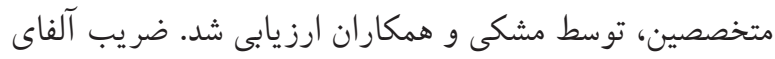

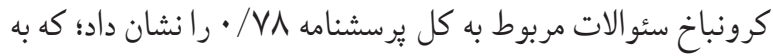

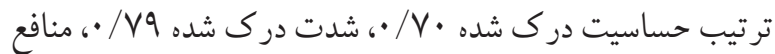
درك شده N9 • •، موانع درك شده V9/ • و رفتار V9/ • بود (19).

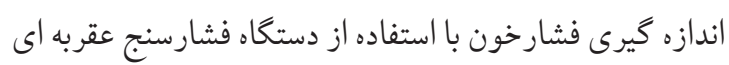
دو شلنكه ريشتر مدل 1350 Exacta و گوشى بز شككى ريشتر مدل انجام شد. همجنين اندازه كيرى قند خون افراد تحت يُزوهش با استفاده از دستگاء كرسنس كه داراى استاندارد

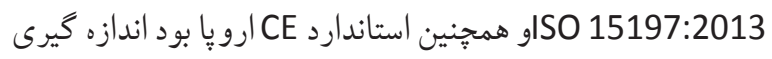
شد. جهت جلو گيرى از خطا انتقال اطلاعات از دستخاه به كامييوتر

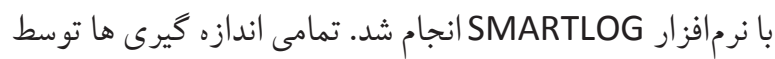
يُوهشكر اول اندازه گيرى و ثبت شد. همجنين سنجش ميزان فعاليت بدنى از طر يق خود گزارشى انجام شد.

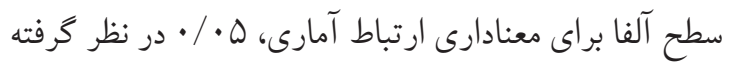

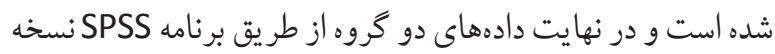

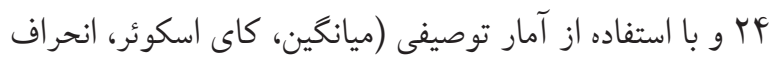
معيار و توزيع فراوانى) و آمار استنباطى (ميانكين و آزمون تحليل

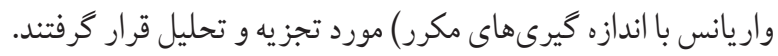


جدول ا: برنامه مداخله آموزشى هفتگى طر احى شده با استفاده از سازههاى الكَوى باور بهداشتى

\begin{tabular}{|c|c|c|}
\hline 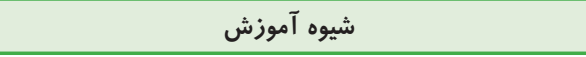 & هدف از آموزش & 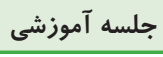 \\
\hline با استفاده از تصاوير آموزشى گروهى & 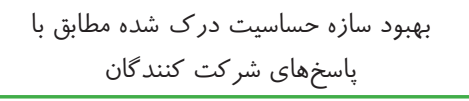 & هفته اول \\
\hline 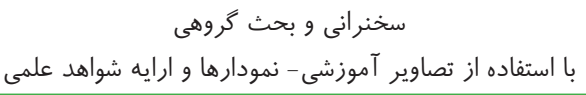 & بهبود سازه حساسيت و شدت درك شده & هفته دوم \\
\hline با استفاده از تصاوير آموزشى - نمودارها و ارايه شواهد على على & بهبود سازه شدت درى شده & هفته سوم \\
\hline بحث و كفتخوى گروهى و مصاحبه انگيزشى & افزايش منافع درك شده و كاهش موانع درى & هفته جهارم \\
\hline تعيين اهداف كوتاه مدت و بحث گروهى & و و افزايش خود كار آمدى & هفته ينجم \\
\hline
\end{tabular}

تاييديه كميته اخلاق دانشكاه و كد اخلاق.IR.TUMS.SPH

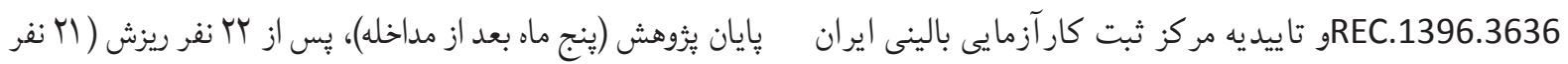

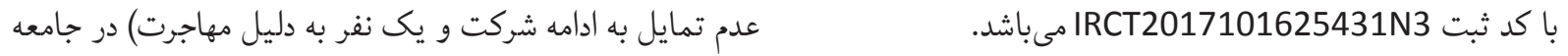

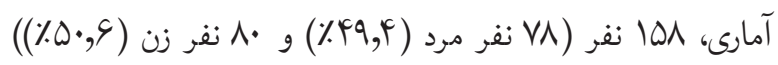

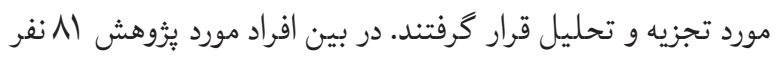
يافته ها

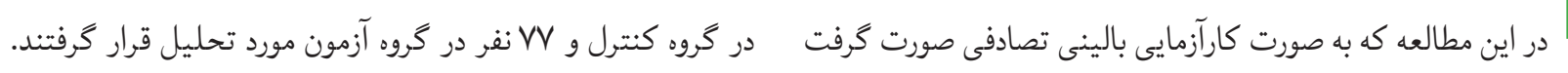

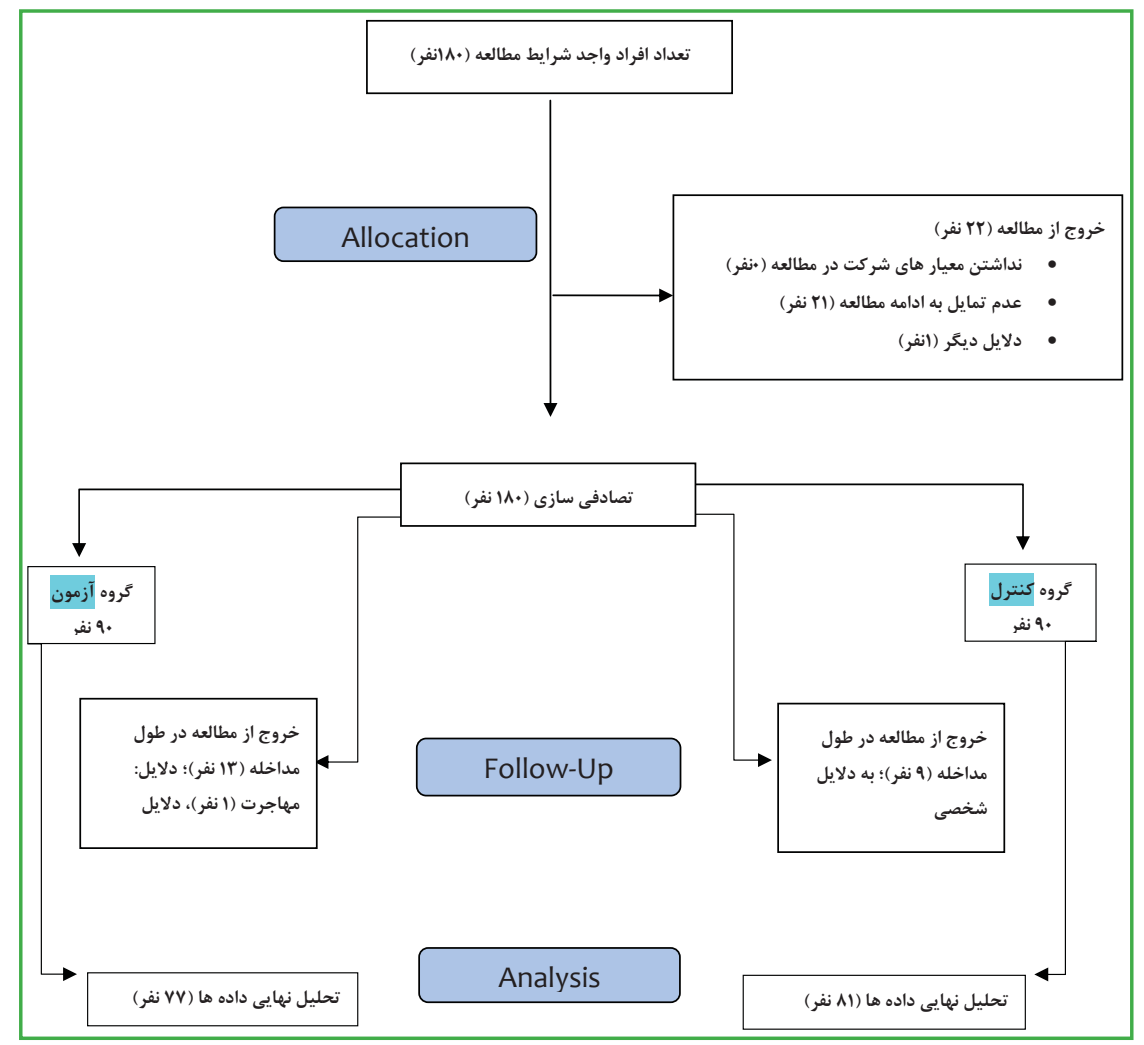

شكل ا: فلوخارت CONSORT شركت كنند كًان در يخوهش 
شكل ا، فلوجارت شركت كنندگان در يُوهش را نشان مى دهد. زمينه اى مانند سن، جنسيت، سطح تحصيلات، وضعيت تاهل، ابتلا

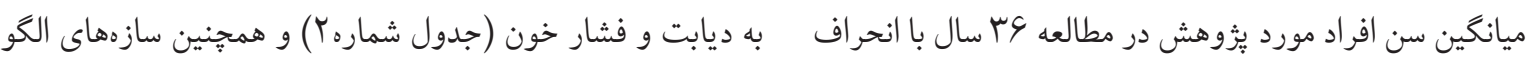

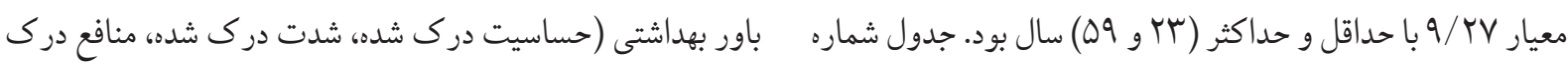

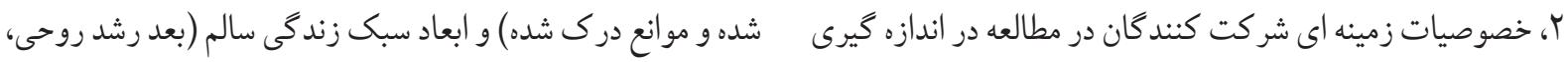

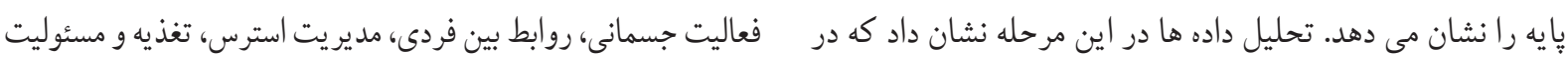

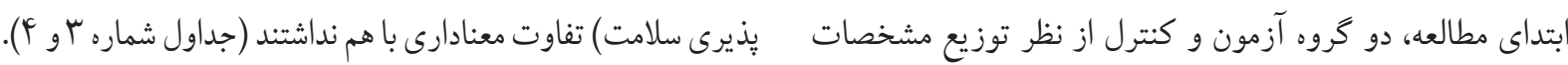
جدول r: توزيع اطلاعات دموكرافيك نمونه يزوهش بر حسب ويثَى هاى جمعيت شناسى در دو گروه آزمون و كنترل قبل از مداخله آموزشى

\begin{tabular}{|c|c|c|c|c|c|c|}
\hline \multirow{3}{*}{ سطح معنادارى } & \multicolumn{4}{|c|}{ كروه } & & \multirow{3}{*}{ متغير } \\
\hline & \multicolumn{2}{|c|}{ كروه كنترل } & \multicolumn{2}{|c|}{ كروه آزمون } & & \\
\hline & درصد & تعداد & درصد & تعداد & & \\
\hline$F q \Delta /$. & $q / \cdot r$ & $r V / V \Delta$ & $9 / \Delta \Lambda$ & $\mathrm{rV} / 90$ & & سن \\
\hline \multirow{2}{*}{$\Delta S Y /}$. & $\% \leftarrow / F q$ & r. & $\% \leftarrow / \& q$ & rᄉ & مرد & \multirow{2}{*}{ جنسيت } \\
\hline & $\% .9 / 01$ & FI & $4 / 01 \%$ & rq & زن & \\
\hline \multirow{2}{*}{ rrs/. } & $\% 9 / 8 V$ & $\Delta \Delta$ & \% & pq & بله & \multirow{2}{*}{ استعمال دخانيات } \\
\hline & $\% 1 / r r$ & rs & $\% \varphi / r s$ & $r \wedge$ & خير & \\
\hline \multirow{2}{*}{ 「^৭/. } & $\% r / r V$ & rr & $\Perp^{\mu} r / \Delta$ & $r \Delta$ & بله & \multirow{2}{*}{ ابتلا به ديابت } \\
\hline & $\%$ N/VY & $\Delta 9$ & $\% .9 \mathrm{~V} / 0$ & $\Delta r$ & خير & \\
\hline \multirow{2}{*}{ rrm/. } & $\% q / r \Delta$ & rl & $\% \Delta / r r$ & ro & بله & \multirow{2}{*}{ بتلا به پرفشارى خون : } \\
\hline & $\% 1 / V F$ & 4. & $\% \Delta / \& V$ & $\Delta r$ & خير & \\
\hline \multirow{2}{*}{$\Delta \cdot \Lambda /}$. & $\% \varphi / r v$ & r & \% & $r I$ & مجرد & \multirow{2}{*}{ وضعيت تاهل } \\
\hline & $\% 9 / \mathrm{VI}$ & $\Delta \Lambda$ & $\% V / V r$ & $\Delta S$ & متاهل & \\
\hline \multirow{6}{*}{$r \cdot q /}$. & $\% 1 / 11$ & 9 & $\% \Delta / 9$ & $\Delta$ & زير دييلم & \multirow{6}{*}{ سطح تحصيلات } \\
\hline & $\% \cdot / r V$ & $r$. & $\% \Delta / r r$ & ro & دييلم & \\
\hline & $\% 1 / 19$ & 19 & $\% 1 / r r$ & IV & كاردانى & \\
\hline & $\% 9 / r^{\prime} q$ & YF & \% & $r F$ & كارشناسى & \\
\hline & $\% \Delta / r$ & r & $\% / 8$ & $\Delta$ & كارشناسى ارشد & \\
\hline & . & . & $\% / 1$ & 1 & د كترا & \\
\hline
\end{tabular}

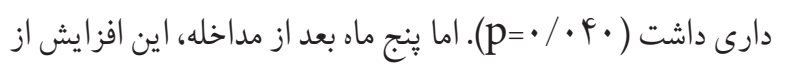

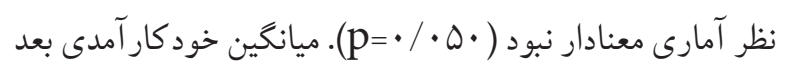

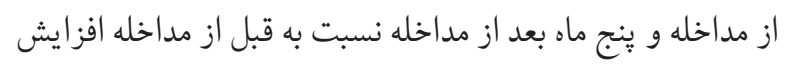

$$
\text { معنى دار آمارى نداشت (جدول مان). }
$$

يافته ها نشان داد كه ميانخين نمره حساسيت درك شده، شدت درك شده و منافع درك شده نيز بعد از مداخله نسبت به قبل از مداخله

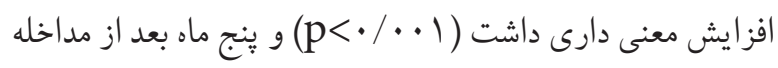
نيز اين افزايش از نظر آمارى معنى دار باقى ماند. ميانكين نمره

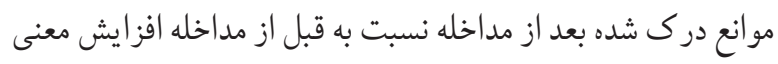


جدول س: مقايسه ميانگين و انحراف معيار سازههاى الگوى باور بهداشتى در بين افراد شركت كننده در يثوهش در گروه آزمون و كنترل قبل و بعد از مداخله

\begin{tabular}{|c|c|c|c|c|c|c|}
\hline \multirow{2}{*}{ p-value } & \multicolumn{2}{|c|}{ كروه آزمون } & \multicolumn{2}{|c|}{ كروه كنترل } & \multirow{2}{*}{ زمان } & \multirow{2}{*}{ متغير } \\
\hline & انحراف معيار & ميانگين & انحراف معيار & ميانگين & & \\
\hline . ITRS & $\mid F / \cdot r$ & $49 / \cdot 1$ & $\mid r / F G$ & $s \mu / g F$ & قبل مداخله & \multirow{3}{*}{ حساسيت درك } \\
\hline$\cdot / \cdots 1$ & $1 r / r q$ & $V \cdot / 91$ & $|r / \mu|$ & $s F / \Lambda \Lambda$ & بعد مداخله & \\
\hline .1 .19 & $\| r / r$. & $s q / r$. & $1 \pi / 19$ & $94 / 90$ & ينج ماه بعد از مداخله & \\
\hline \multicolumn{7}{|c|}{ تحليل واريانس } \\
\hline$\cdot / V S D$ & $1 r / 9$. & $\Delta Q / \Delta \varphi$ & $\mid r / \Delta \varphi$ & $9 \cdot 119$ & قبل مداخله & \multirow{3}{*}{ شدت درى شده } \\
\hline$\cdot / \cdots$ & $|f /|$ & $S F / S V$ & $I Y / T F$ & $G \cdot / G q$ & بعد مداخله & \\
\hline$\cdot / \cdot$ ץ & $I Y / \Lambda F$ & $S Y / \Delta 1$ & $\mid r / M \Lambda$ & SI/GF & ينج ماه بعد از مداخله & \\
\hline \multicolumn{7}{|c|}{ تحليل واريانس } \\
\hline$\cdot / \cdot \wedge$ & $1 \cdot / V$ & $s q / \Delta V$ & $\mid r / F G$ & $4 \mid / \mu 1$ & قبل مداخله & \multirow{3}{*}{ منافع درى شده } \\
\hline$\cdot / \cdot 1$ & $1 \cdot / 11$ & $S V / T$. & $11 / \% s$ & $S Y / V V$ & بعد مداخله & \\
\hline$\cdot / \cdot 1 r$ & $9 / \lambda F$ & س س & $11 /$ N & SY/DI & ينج ماه بعد از مداخله & \\
\hline \multicolumn{7}{|c|}{ تحليل واريانس } \\
\hline$\cdot / 9 \vee \wedge$ & $1 r / 91$ & $\Delta S / V I$ & $\mid F / 90$ & $\Delta \Delta / V \varphi$ & قبل مداخله & \multirow{3}{*}{ موانع درك شده } \\
\hline.$/ \cdot \varphi$ & $\mid f / \cdot 1$ & ST/AV & $10 / 11$ & $\Delta Q / T \Delta$ & بعد مداخله & \\
\hline$\cdot / 0 \cdot r$ & $\mid r / \Delta s$ & $\Delta Q / \Delta r$ & $1 \pi / v 0$ & $\Delta \Lambda / \cdot q$ & ينج ماه بعد از مداخله & \\
\hline \multicolumn{7}{|c|}{ تحليل واريانس } \\
\hline$\cdot 19 \cdot 9$ & $10 / 01$ & $s \cdot / \Lambda \Lambda$ & $|r / r|$ & $41 / 1 \mu$ & قبل مداخله & \multirow{3}{*}{ خود كار آمدى } \\
\hline .1 .99 & 1r/9r & $S Y / 9 G$ & II/Ar & $G r / \cdot r$ & بعد مداخله & \\
\hline (Ir & 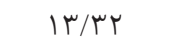 & $s \mu / \wedge q$ & $|1 / 4|$ & $s \mu / \cdot 1$ & ينج ماه بعد از مداخله & \\
\hline \multicolumn{7}{|c|}{ تحليل واريانس } \\
\hline
\end{tabular}

Repeated measures ANOVA*

تحليل ابعاد سبك زندگى نشان داد كه بجز ميانگين نمره رشد روابط بين فردى، مديريت استرس، فعاليت جسمانى، و تغذيه) بعد

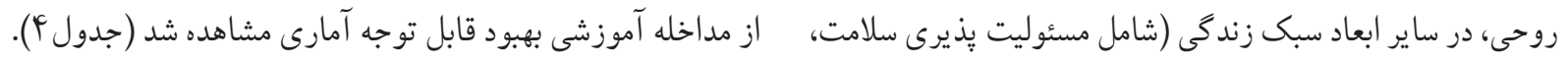


جدول عا: مقايسه ميانگين و انحراف معيار ابعاد رفتارهاى ارتقادهنده سبك زندگى در يين افراد شركت كننده در يثوهش در گروه آزمون و كنترل قبل و بعد از مداخله

\begin{tabular}{|c|c|c|c|c|c|c|}
\hline \multirow[t]{2}{*}{ p-value } & \multicolumn{2}{|c|}{ كروه آزمون } & \multicolumn{2}{|c|}{ گروه كنترل } & \multirow{2}{*}{ ز مان } & \multirow{2}{*}{ متغير } \\
\hline & انحراف معيار & ميانغين & انحر اف معيار & ميانغين & & \\
\hline$\cdot / 1 \cdot 9$ & $1 \cdot / 41$ & $F G / T V$ & $1 \pi / .9$ & $r \Delta / \Lambda 1$ & قبل مداخله & \\
\hline $.1 \cdot 9$ & $11 / \cdot r$ & $0 \cdot 10$ & $1 r / \lambda$ & $\varphi \wedge / \varsigma q$ & بعد مداخله & بعد رشد روحى \\
\hline$\cdot / \wedge$ & $\mid r / \cdot 1$ & $F V / r \mu$ & $\mid F / V F$ & $\mathrm{FV} / \cdot \mathrm{l}$ & ينج ماه بعد از مداخله & \\
\hline \multicolumn{7}{|c|}{ تحليل واريانس* } \\
\hline.$/ 9 s 4$ & $|r / r|$ & $r \Delta / V r$ & Ir/ג & $r \Delta / s r$ & قبل مداخله & \multirow{3}{*}{ يذيرى سلامت مسئوليت } \\
\hline$\cdot / \cdots 1$ & Ir/Ar & $r q / V r$ & ס & $r \Delta / 9 \mu$ & بعد مداخله & \\
\hline$\cdot / \Lambda F V$ & $\mid r / 4 \Lambda$ & $F V / F$. & $\mid r / 1 \wedge$ & $F V / 11$ & ينج ماه بعد از مداخله & \\
\hline \multicolumn{7}{|c|}{ تحليل واريانس } \\
\hline . & $9 / \wedge$. & $r V / I r$ & $1 r / \cdot r$ & $F S / F \Delta$ & قبل مداخله & \multirow{3}{*}{ بعد روابط بين } \\
\hline$\cdot 1 \cdots 1$ & $1 \cdot / 1 F$ & $r q / q r$ & $|r / \Lambda|$ & $\varphi \& / 0$. & بعد مداخله & \\
\hline .1190 & $1 \cdot / 94$ & rq/Ar & $1 r / 90$ & $\varphi \vee / \wedge q$ & ينج ماه بعد از مداخله & \\
\hline \multicolumn{7}{|c|}{ تحليل واريانس } \\
\hline$\cdot / V 10$ & $1 r / 9 \Lambda$ & rN/vi & $|F / T|$ & $\mu q / \Delta$. & قبل مداخله & \multirow{3}{*}{ بعد مديريت } \\
\hline$\cdot 1 \cdot \cdot 1$ & $\mid r / r \Delta$ & $F 1 / \Delta 0$ & $\mid F / S V$ & $r \cdot / \cdot r$ & بعد مداخله & \\
\hline$\cdot|r r|$ & Ir/VO & $|\uparrow| / 1 \wedge$ & $10 / 9 F$ & $f 1 / \cdot r$ & ينج ماه بعد از مداخله & \\
\hline \multicolumn{7}{|c|}{ تحليل واريانس } \\
\hline . MFr & $q / \Delta r$ & $r \cdot / r \Delta$ & $q / \mathbb{c} \Delta$ & rq/Vq & قبل مداخله & \multirow{3}{*}{ جسمانى فعاليت } \\
\hline$\cdot / \cdots 1$ & $1 \cdot / r 1$ & Fr/GG & $q / \Delta r$ & $r q / \cdot r$ & بعد مداخله & \\
\hline$\cdot / \Delta S \mu$ & $9 / 9$. & $f \mid / 9 \pi$ & $q / 41$ & $f 1 / \cdot r$ & ينج ماه بعد از مداخله & \\
\hline \multicolumn{7}{|c|}{ تحليل واريانس } \\
\hline$\cdot / 9 \cdot 1$ & $1 r / \cdot r$ & rN/DT & $\mid r / 4 \Lambda$ & 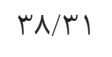 & قبل مداخله & \multirow{3}{*}{ بعد تغذيه } \\
\hline$\cdot 1 \cdot .1$ & $11 / 40$ & $q \mu /$. & Ir/r. & $\boldsymbol{\mu} N \cdot \boldsymbol{r}$ & بعد مداخله & \\
\hline.$/ 10$ & $11 / 21$ & $r \cdot / r$ & $I r / I V$ & $\mu q / \ldots$ & ينج ماه بعد از مداخله & \\
\hline \multicolumn{7}{|c|}{ تحليل واريانس } \\
\hline
\end{tabular}

Repeated measures ANOVA*

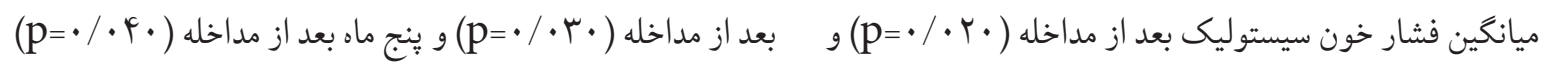

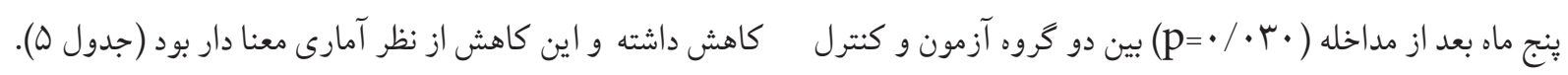

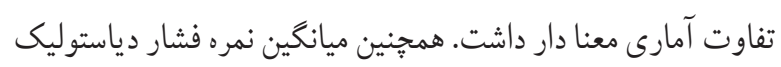


جدول ه: مقايسه ميانكَين و انحراف معيار فشارخون* در بين افراد شركت كننده در يثوهش در گَروه آزمون و كنترل قبل و بعد از مداخله

\begin{tabular}{|c|c|c|c|c|c|c|}
\hline \multirow[t]{2}{*}{ p-value } & \multicolumn{2}{|c|}{ كروه آزمون } & \multicolumn{2}{|c|}{ كروه كنترل } & \multirow{2}{*}{ زمان } & \multirow{2}{*}{ متغير } \\
\hline & انحراف معيار & ميانگين & انحراف معيار & ميانغين & & \\
\hline$\cdot|c|$ & $10 / 4 \Delta$ & $\mid r s / F q$ & $1 r / 11$ & $\mid r F / s q$ & قبل مداخله & فشيستوليكى \\
\hline$\cdot / r \Delta S$ & $1 r / \cdot r$ & $\Lambda \Delta / V V$ & $1 \cdot / 9$ & $\wedge \mathrm{F} / \cdot \mathrm{l}$ & قبل مداخله & دياستوليكى \\
\hline /. & $\mid r / \varphi \Delta$ & $1 r r / v s$ & $1 r / 99$ & $I F F / F F$ & بعد مداخله & فشيستوليكى \\
\hline d & $1 \cdot / 90$ & $\wedge \mu / \vee$. & $q / \cdot r$ & $\Lambda r / 9 \Delta$ & بعد مداخله & دشاستوليكى \\
\hline$\cdot / \cdot \mu_{1}$ & $1 . / 1 \mathrm{~V}$ & $1 r r / v q$ & $11 / 49$ & Irr/ve & ينج ماه بعد از مداخله & فيستار خون \\
\hline \multicolumn{7}{|c|}{ تحليل واريانس } \\
\hline.$/ .40$ & $q / \mathbb{* V}$ & $\Lambda T / r V$ & $9 / \mu r$ & $\Lambda r / 90$ & ينج ماه بعد از مداخله & دياستوليكى \\
\hline
\end{tabular}

* ميانگين فشار خون بر حسب ميلى متر جيوه

مقايسه ميانكين شاخص توده بدنى را در شر كت كنند گان در ميانگين نمره فعاليت جسمانى ينج ماه بعد از مداخله نسبت به قبل

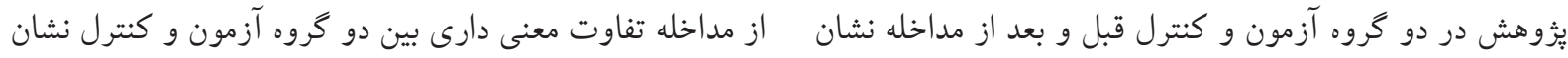

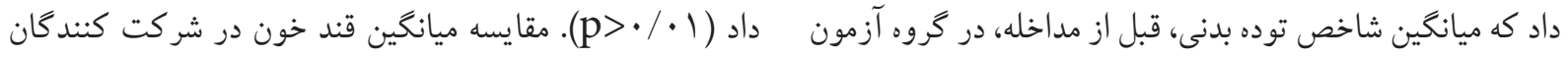

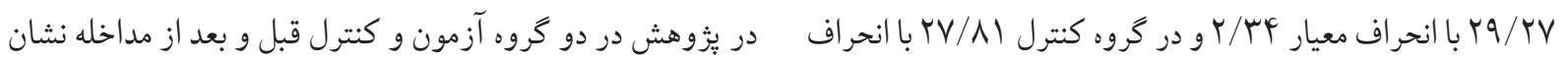

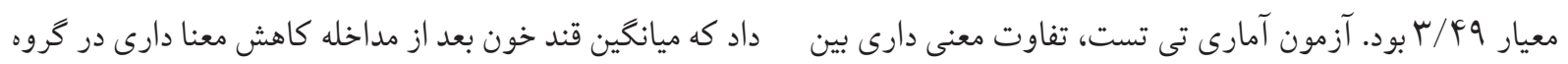

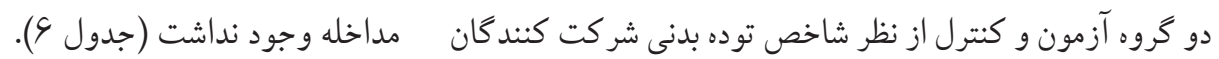

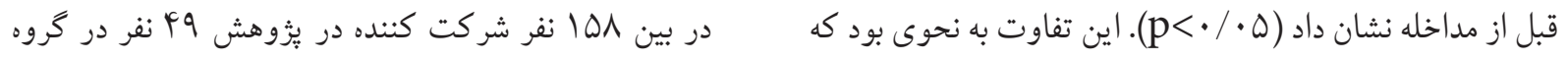

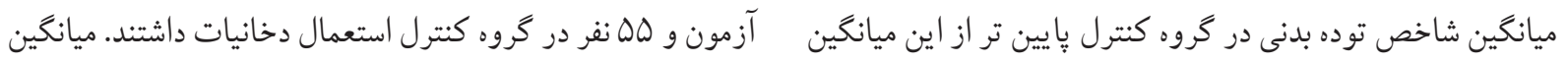

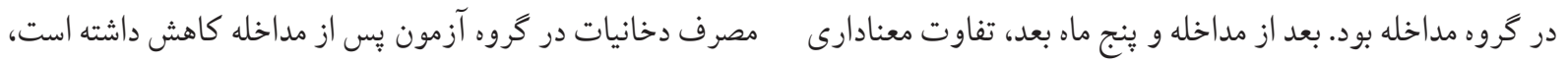

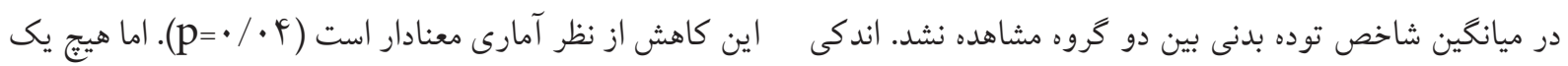

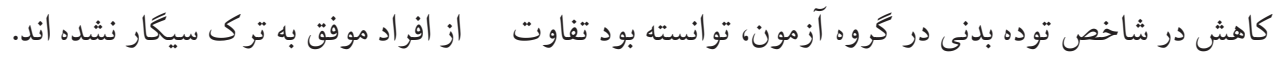
معنى دار ابتداى مطالعه را از بين ببرد.

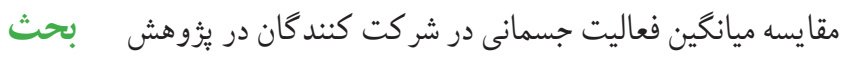

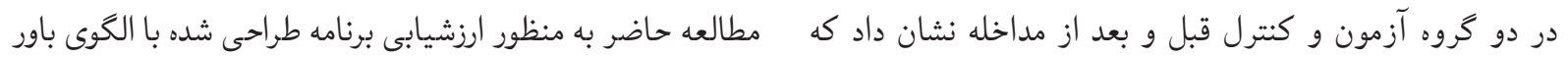

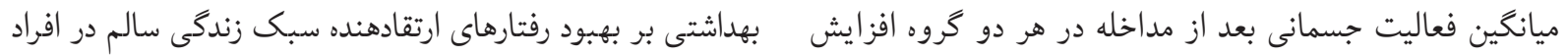

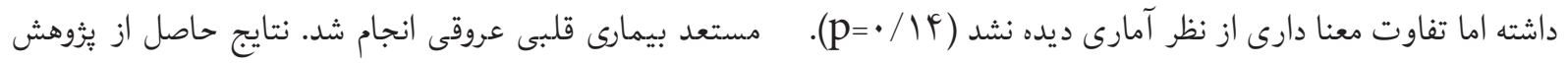


جدول 9: مقايسه ميانكين و انحراف معيار فعاليت جسمانى ميزان قند خون و استعمال دخانيات در يُزوهش در گروه آزمون و كنترل قبل و بعد از مداخله

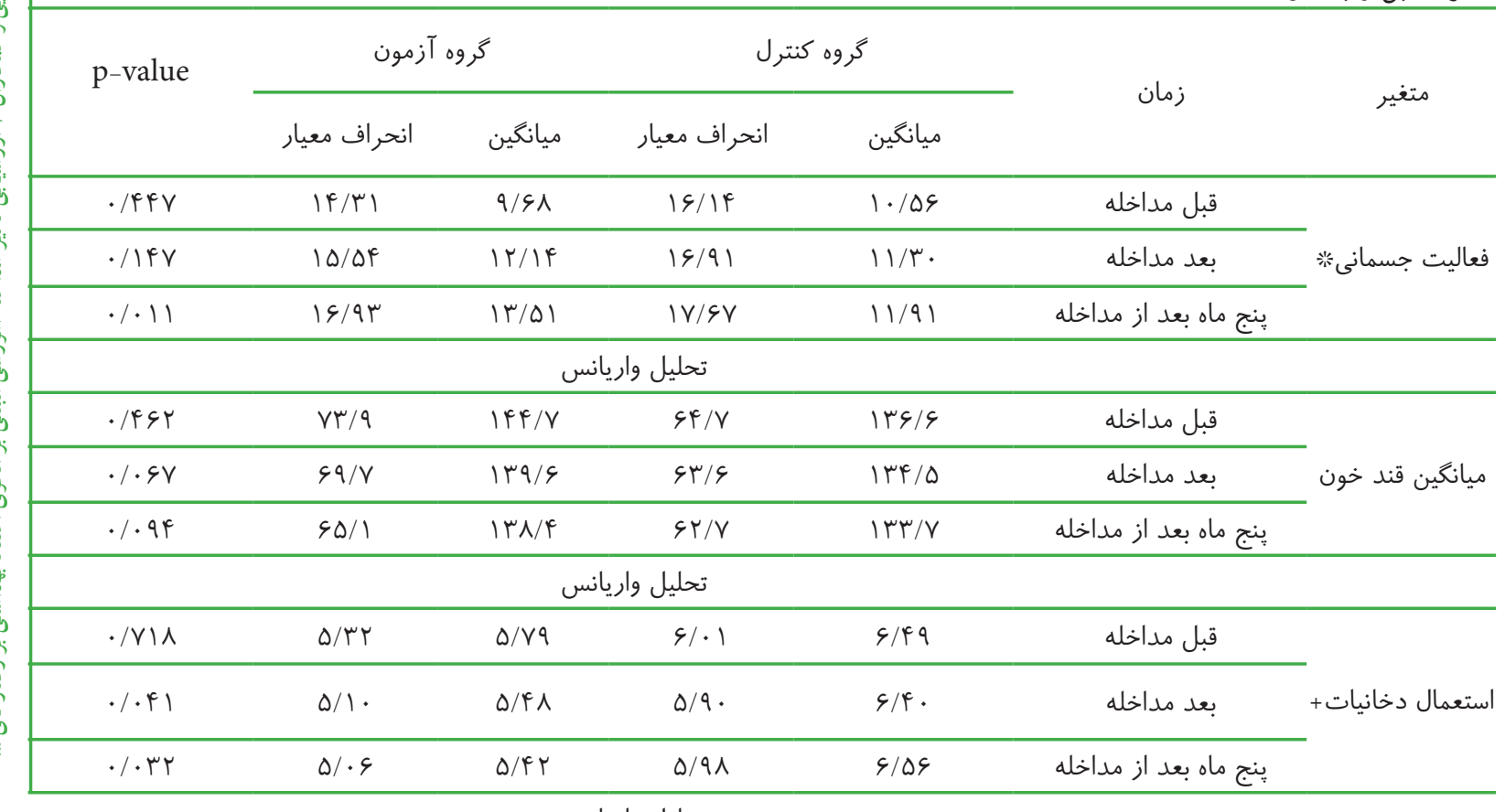

تحليل واريانس

ثبر حسب دقيقه در طول شبانه روز +بر حسب تعداد نخ در طوب شبانه روز

هدف بررسى تاثير برنامه طر احى شده ارتقاى سلامت بر مديريت

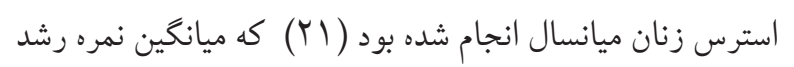
روحى اختلاف آمارى معنادارى داشته انجام شد بود نا همسو بود.

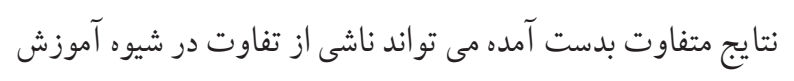
و مدت زمان مداخله آموزشى باشد.

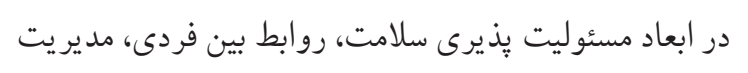

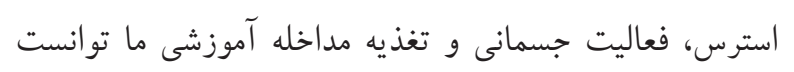

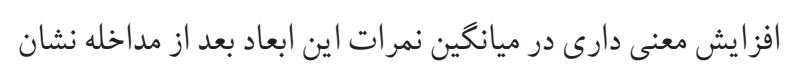

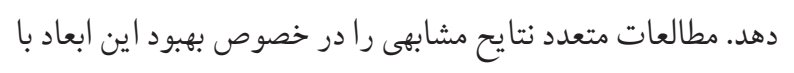

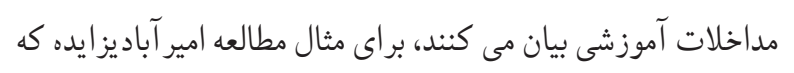

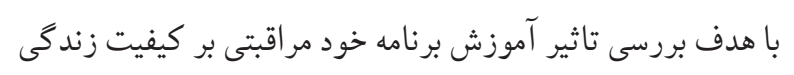

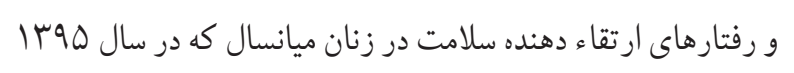
انجام شده بود كه رفتارهاى ارتقاء دهنده سلامت در گرووه مداخله

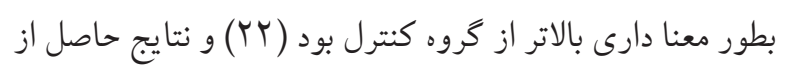

نشان داد كه مداخله آموزشى بر بهبود برخى از ابعاد سبك زندگى،

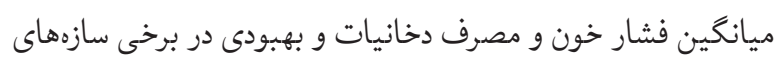
الخوى اعتقاد بهداشتى موثر بود. بررسى تاثير مداخله آموزشى بر ابعاد سبك زندگى سالم كه بود

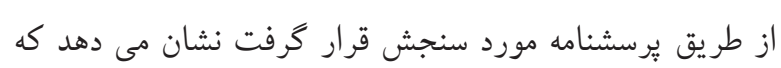

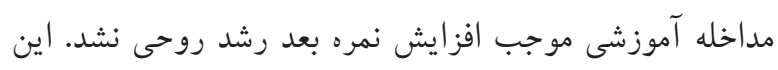
نتايج، با يافتهاى كزارش شده از مطالعه مصطفى نثاد و همكاران

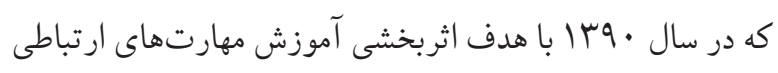

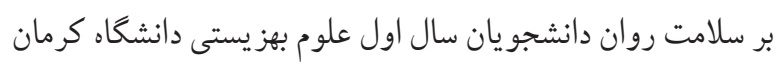

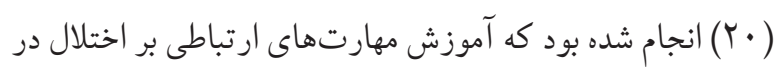
خواب و اضطر اب و افسردگى دانشجويان تأثير معنىدارى نداشته

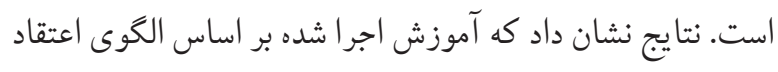
بهداشتى نتوانست سبب بهبود رشد روحى شود. همجنين نتايج

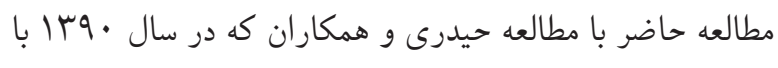


پذير باشد. در نظر گرفتن محيط ويرامون به عنوان يك فاكتور در

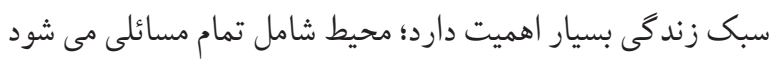

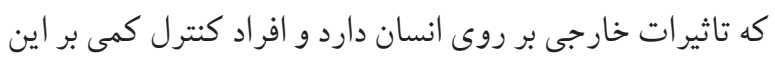
عوامل دارند يا اصلا ندارند. به عنوان مثال شخصى كه در بيى انجام

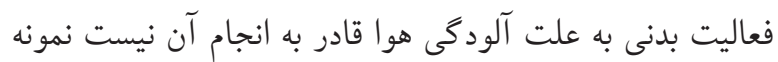
اي از شرايط محيطى است كه شخص قادر به كنترل آن نيست. اين موضوع نشان مى دهد كه به كار بردن يك مدل تغيير رفتار فردى، هر جند مى تواند منجر به تغيير رفتار كو تاه مدت شود اما

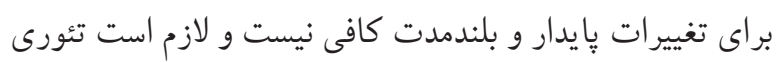

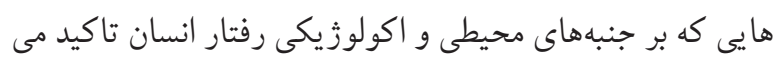
كنند هم مورد بررسى و استفاده قرار كيرند. نتايج اين مطالعه نشان داد كه ميانگين نمر ات حساسيت، شدت،

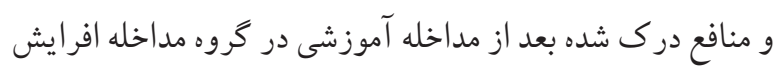

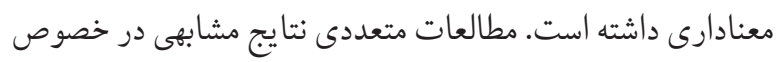

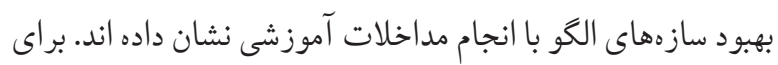
مثال، نتايج مطالعه زينلى و همكاران كه در سال سوس بال با بأ عنوان بررسى تأثير مداخله آموزشى بر اساس الخوى اعتقاد بهداشتى بر مئر

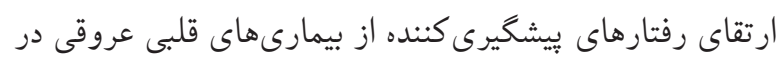

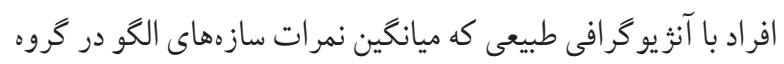

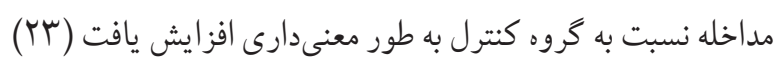

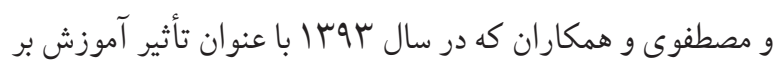
آكاهى و نكخش دانش آموزان شهر ايذه در مورد بيمارىهاى قلب دهان

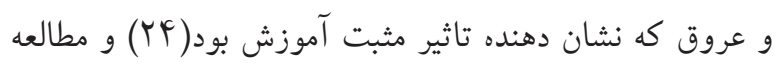

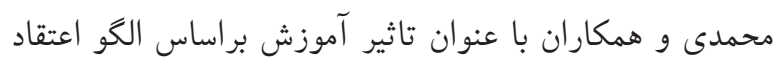

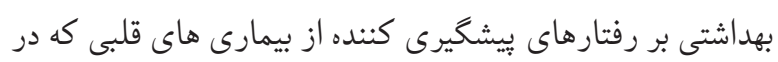

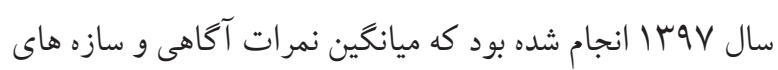

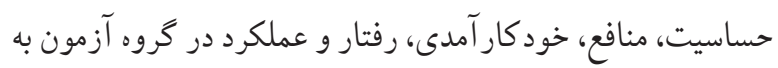
طور معنى دارى افزايش بيدا كرد (TO) و مطالعه فانى و همكاران

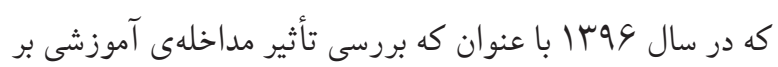

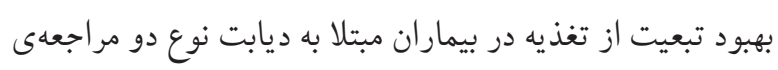

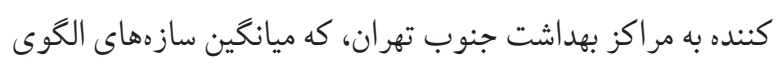

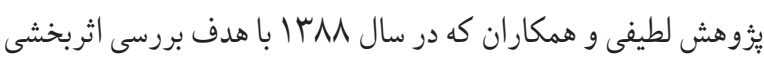

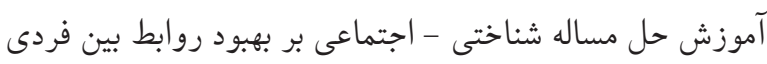

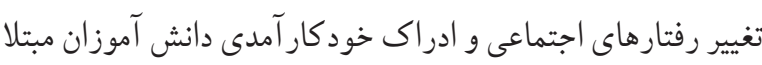
به ناتوانى ياد گيرى كه منجر به افزايش خود كار آمدى اجتماعى آنان آنان

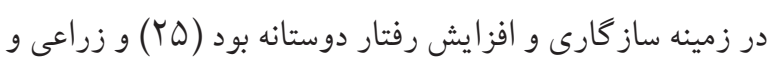

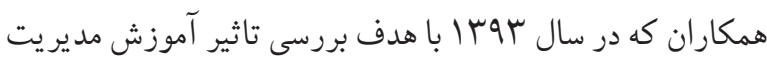

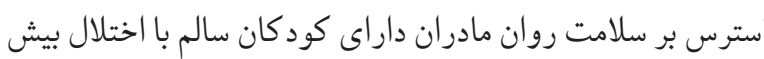
فعالى كه اثربخشى تأثير آموزش مدير يت استرس به شيوه شناختى دانى داري رفتارى بر سلامت روان مادران را تاييد مى كند كه ميانكين نمره استرس در گروه مداخله كاهش يافته بود (YV) و مطالعه مسرور

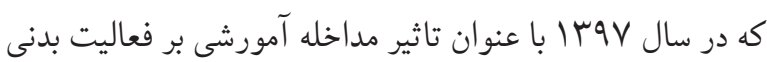

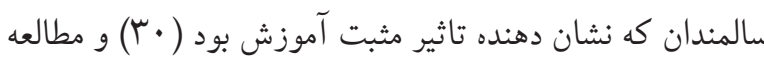

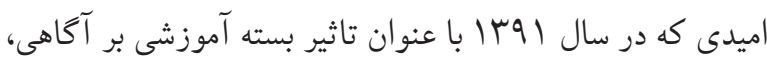

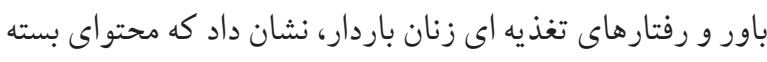
آموزشى تهيه شده توانست باعث ارتقاى آكاهى، باور و رفتار تغذيهاى زنان باردار شود (آس) همسو بود. همانطور كه نتايج مطالعه نشان مى دهد در بيشتر ابعاد سبك ئرد

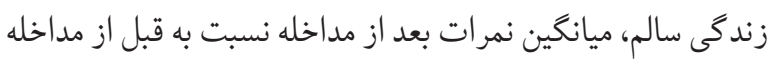

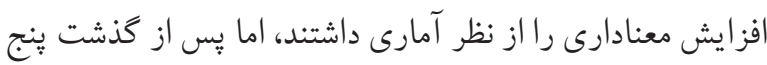

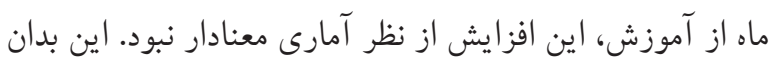

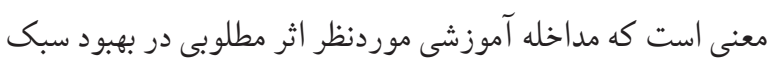

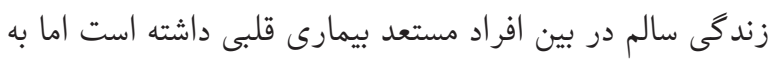

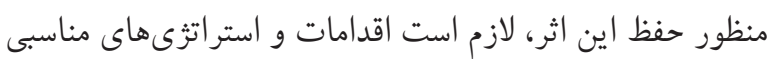

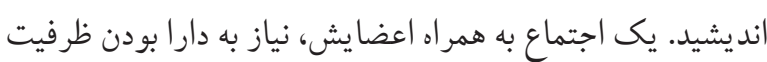

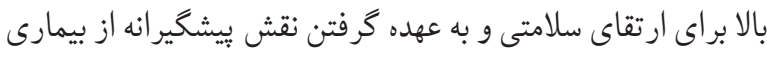

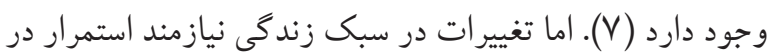

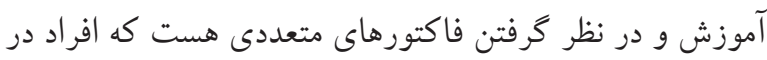

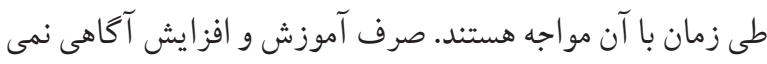

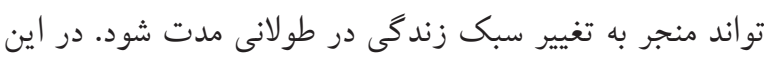
مسئله نياز است كه عوامل متعدد و بى شمار قابل تعديل را در كنار هم قرار دهيم تا تغيير و حفظ تمامى ابعاد سبك زندكى سالم امكان 
و اين تغييرات از نظر آمارى معنادار بود. مطالعات متعددى نتايج

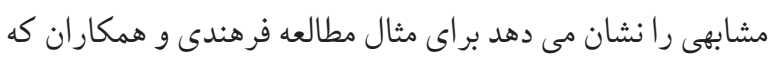

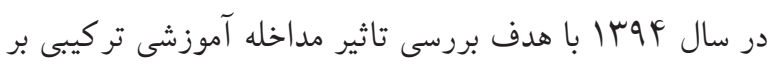

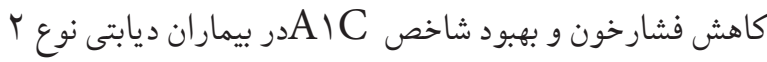

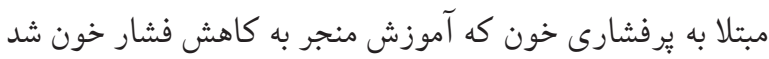

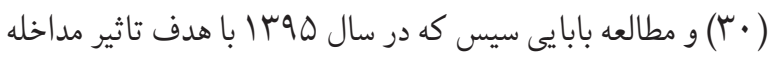

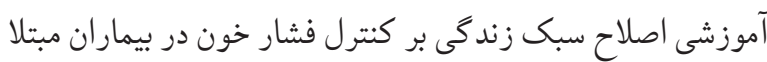

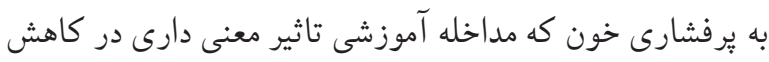

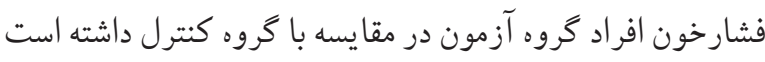

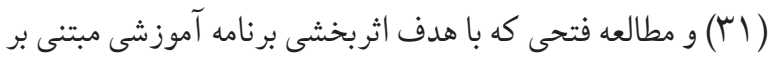

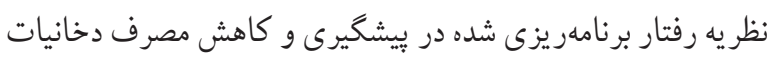

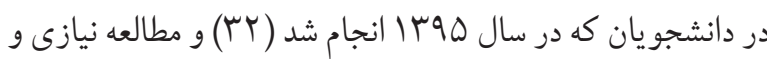

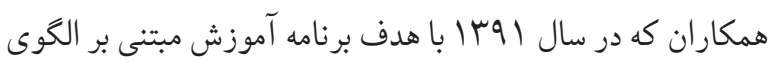

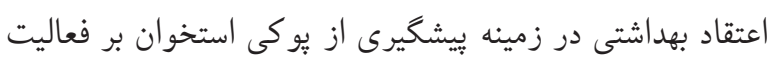

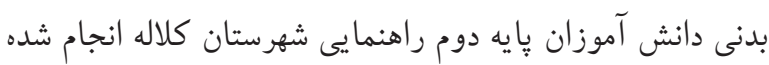

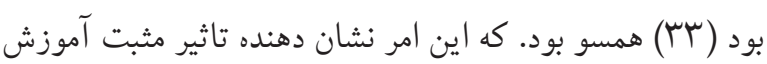
در كاهش رفتارهاى ير خطر مى باشد.

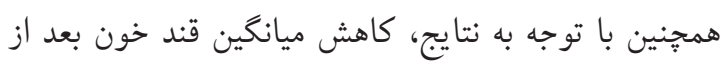

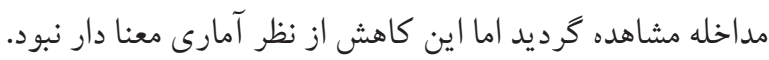

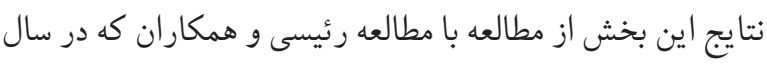

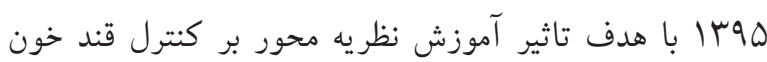

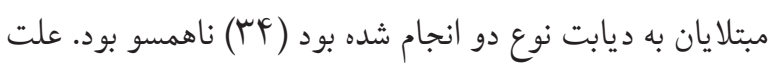

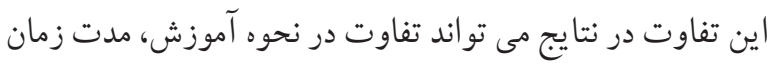

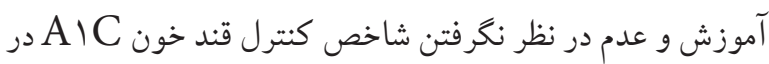

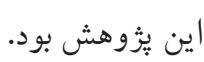

از نقاط قوت اين يُّوهش، عدم تكيه بر يرسشنامه و اندازه

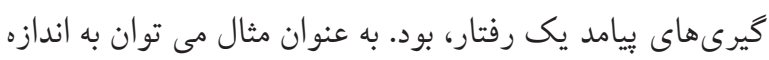

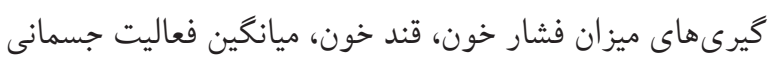
و مصرف دخانيات اشاره كرد. يكى از اصلى ترين نقاط ضعف اين يُوهش در نظر نكرف فتن

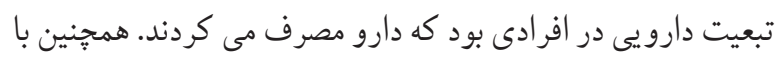

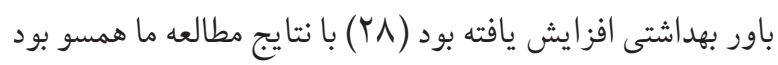

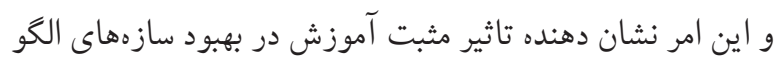
اعتقاد بهداشتى مى باشد.

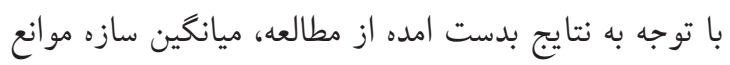

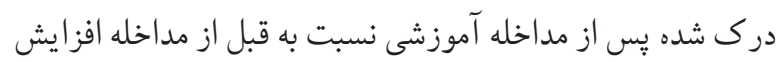

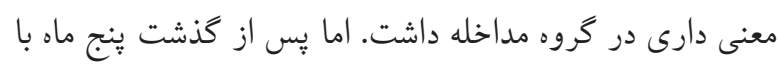
وجود افزايش در ميانكين سازه نسبت به قبل از مداخله، اين افزايش

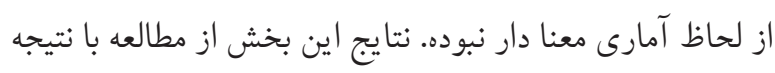

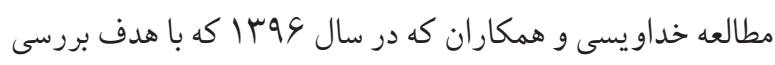
بيش بينى عوامل موثر بر رعايت احتياطات استاندارد كنترل عفونت

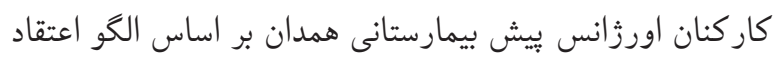

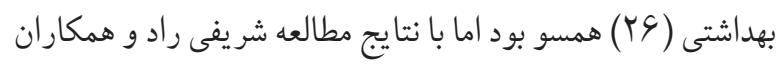

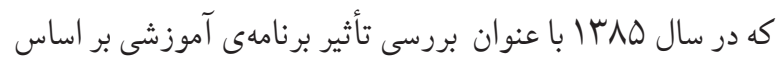

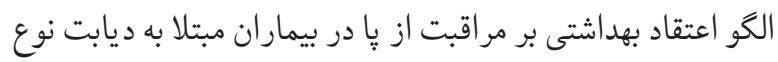

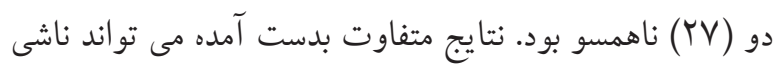

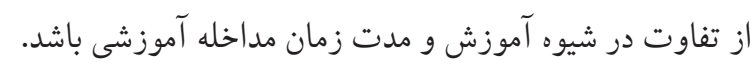

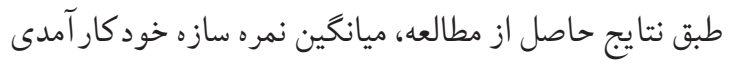

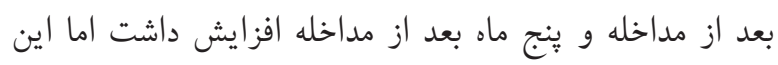

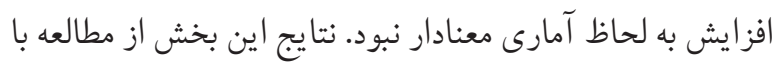

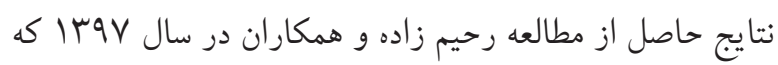

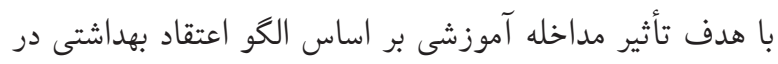

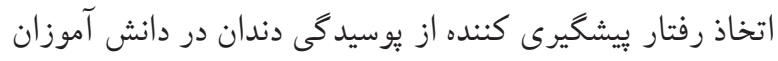

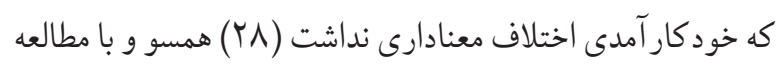

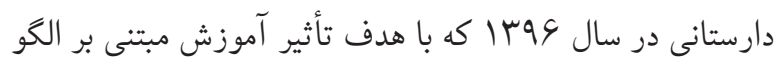

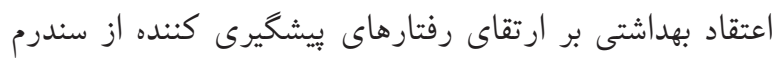

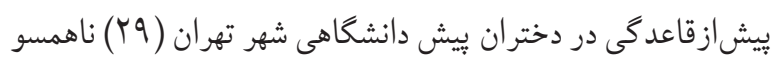

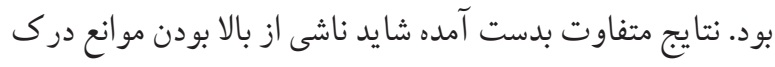
شده و تفاوت در مدت و نحوه آموزش باشد.

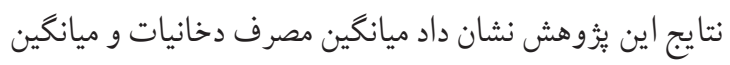
فشار خون بعد از مداخله كاهش داشت. همجنين فعاليت جسمانى ينج ماه بِ از مداخله نسبت به قبل از مداخله افزايش داشته است 
يُوهش هاى ديكرى كه در اين حوزه مى توان انجام شود استفاده

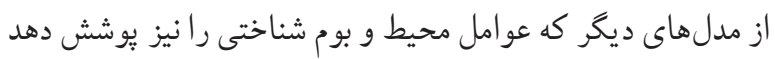

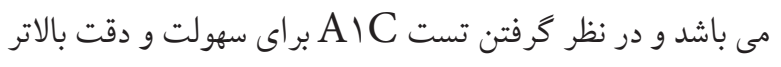
براى اندازه گيرى قند خون و در نظر گرفتن و استفاده از إيليكيشن

$$
\begin{aligned}
& \text { ها در جهت تبعيت دارويى است. } \\
& \text { نتيجاه كيرى }
\end{aligned}
$$

مداخله مبتنى بر الخوى تغيير رفتار فردى منجر به بهبود برخى از ابعاد سبك زندگى، سازهاى الخو، و بيامدهاى بالينى شد. به منظور

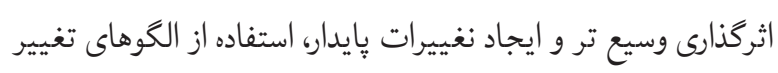

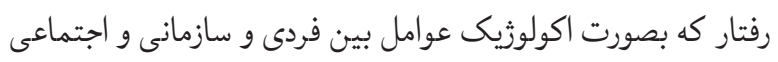
را نيز مدنظر قرار دهند بيشنهاد مى شود. تقدير و تشكر از جناب آقاى مهدى مشكى جهت در اختيار كذاشتن يرسشنامه

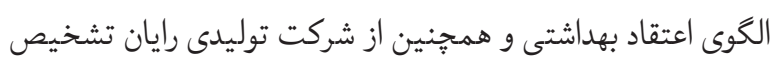

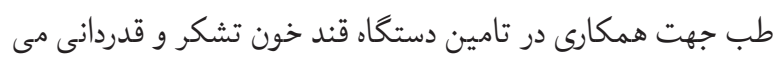

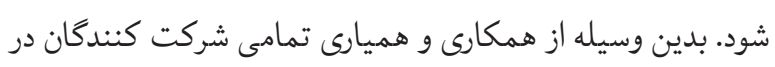

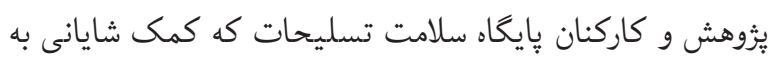
اجراى مطالعه كردند تشكر مى كنيم. تضاد منافع: هيج گونه تضاد منافعى وجود ندارد.

\section{Reference}

1. Nordlie MA, Wold LE, Kloner RA. Genetic contributors toward increased risk for ischemic heart disease. Journal of molecular and cellular cardiology. 2005;39(4):667-79.

2. t. K, gh.r. S. Ten-year changes in mortality and risk factors in acute myocardial infarction in Birjand (1994-2003).

3. Organization WH. World health statistics 2016: monitoring health for the SDGs sustainable development goals: World Health Organization; 2016.

4. Shakeri J, Jaberghaderi N, Rezaei M, Saeedi M, Naleini M, Moloodi A. Psychosocial risk factors in patients with cardio-vascular diseases in Kermanshah (2006) Journal of Kermanshah University of Medical Sciences (J Kermanshah Univ Med Sci). 2012;16(3):246-54.

5. Shahsavari S, Nazari F, Karimyar Jahromi M, Sadeghi R. Epidemiologic study of hospitalized cardiovascular patients in Jahrom hospitals in 2012- 2013.

6. Kavey R-EW, Daniels SR, Lauer RM, Atkins DL, Hayman
توجه به اينكه رفتار تحت تأثير عوامل مختلفى مى باشد كه در بالا به

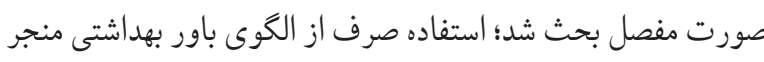
به جشم يوشى از برخى از اين عوامل مثل محيط و بوم شناختى شد.

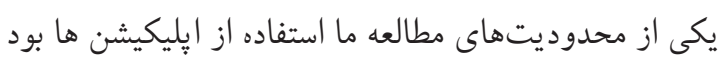

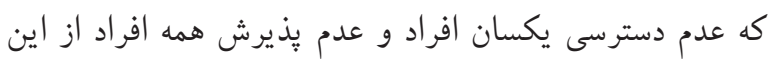

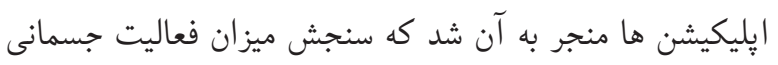

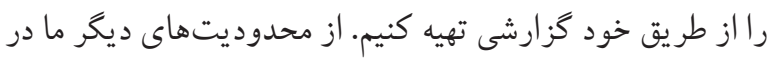

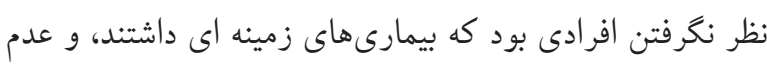

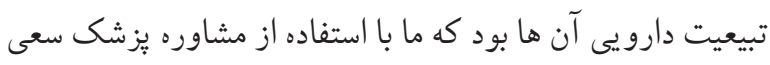

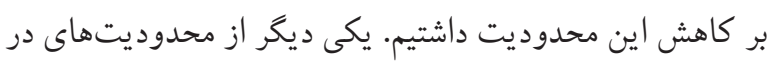

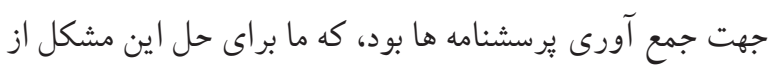

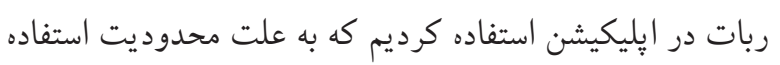
از اين إيليكيشن اين مشكل باقى ماند.

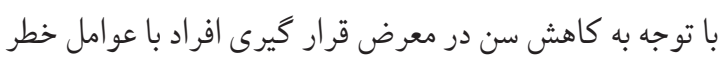

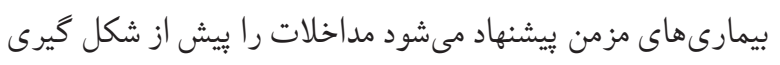

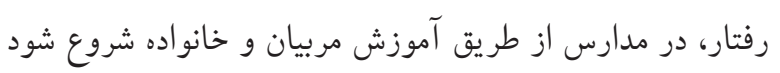

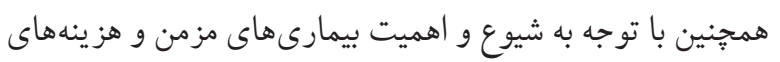

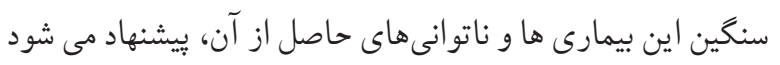

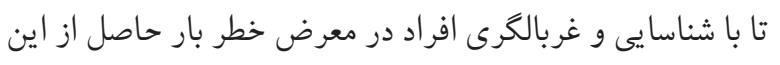

$$
\text { بيمارها را كاهش دهيم. }
$$

LL, Taubert K. American Heart Association guidelines for primary prevention of atherosclerotic cardiovascular disease beginning in childhood. Circulation. 2003;107(11):1562-6.

7. Lyons R, Langille L. Healthy lifestyle: strengthening the effectiveness of lifestyle approaches to improve health. Edmunton (AB): Health Canada. 2000.

8. Tones K, Green J. Health promotion: planning and strategies: Sage; 2004.

9. Saffari M. Theories, models and methods of health education and health promotion. Iran: Sobhan; 2014.

10. Peyman N, Rezai-Rad M, Tehrani H, Gholian-Aval M, Vahedian-Shahroodi M, Heidarian Miri H. Digital Mediabased Health Intervention on the promotion of Women's physical activity: a quasi-experimental study. BMC Public Health. 2018;18(1):134.

11. Lo SWS, Chair SY, Lee FK. Factors associated with health- 
promoting behavior of people with or at high risk of metabolic syndrome: based on the health belief model. Applied Nursing Research. 2015;28(2):197-201.

12. Thalacker KM. Hypertension and the hmong community: using the health belief model for health promotion. Health promotion practice. 2011;12(4):538-43.

13. Chatripour R SD, Tol A, Sayehmiri k ,Asfeia A ,Kia F. the impact of teacher education on promoting knowledge, attitude and performance of students in prevention of cardiovascular diseases: application of the HBM model. Razi journal of medical sciences (journal of Iran university of medical sciences). 2016;23(146):-.

14. Longo DL, Fauci AS, Kasper DL, Hauser SL, Jameson J, Loscalzo J. Harrison's principles of internal medicine. 18. Auflage, MacGraw-Hill Companies Inc, New York. 2012.

15. Besharat Mohanad A. Reliability and Validity of the 28-Question Form of Mental Health Scale in Iranian Population. Journal of Forensic Medicine.

16. Goldberg DP, Hillier VF. A scaled version of the General Health Questionnaire. Psychological medicine. 1979;9(1):139-45.

17. Besharat MA. Reliability and Validity of the 28-Question Form of Mental Health Scale in Iranian Population. Scintific Journal of Forensic Medicine. 2009;15.

18. A. Mz. Validity and reliability of the Persian version of health promoting lifestyle questionnaire. Journal of Mazandaran university of medical sciences. 2011.

19. Mojadam M, Irani Dosti A. Associated Factors for Preventive Behaviors of Cardiovascular Diseases in Employees of Khuzestan Province Health Center Utilizing the Health Belief Model. Journal of Health. 2015;6(4):36777.

20. Nezhad: PM, Dortaj F. Analysis effect of training communication skills on mental-health- of first level of well-being life science university of Kerman. Journal of Psychological Studies. 2012;1(4):70-90.

21. Heidari F., Mohammadkhan Kermanshahi S., Vanaki Z., A. KN. A survey the effect of planned program of health promotion on stress management in middle-aged women. Iranian journal of nursing research. 2011.

22. Amirabadizadeh Z. Survey the effect of education self-care program on quality of life and health promotion behaviors in middle-aged women.

23. Zainali m Am, Aghamolaei T, Esmaeili Nadimi A, Farshidi H, Ghanbarnejad A. Effect of educational intervention based on health belief model to promote preventive behaviors of cardiovascular disease in people with normal angiographic results. Journal of Preventive Medicine. 2015;1(2):1-12.

24. Mostafavi F, Salahshouri S, Jiba M, Harooni J, A S. The effect of educational intervention on knowledge and attitude of students in Izeh about cardiovascular disease: Application of the Health Belief Model. Health System
Research. 2015;11(2):239-49.

25. Mohamadi N SN, Amini R*, Tapak L. The Effect of Education Based on Health Belief Model on Preventive Behaviors Towards Cardiovascular Disease. Avicenna journal of nursing and midwifery care. 2018;26.

26. Khodisiave M MM, Amini R, Karami M. Factors Predicting the Standard Precautions for Infection Control among Prehospital Emergency Staff of Hamadan Based on the Health Belief Model. J Educ Community Health. 2017;4(3):12-8.

27. Gh Sharifirad SH, S Mohebi, MA Rahimi, A Hasanzadeh. The effect of educational programme based on Health Belief Model (HBM) on the foot care by type II diabetic patients. Iranian Journal of Endocrinology and Metabolism. 2006;8(3):231-9.

28. Aredeshir Rahimzadeh PFS, Khaled Rahmani, Sharareh Bagheri. Effect of a Training Intervention Program Designed Based on Health Belief Model on Adopting Behaviors Preventing Dental Caries in Students. Iran J Health Educ Health Promot. 2018;6(3):0-

29. Khalilipoor darestani M, Komeili A, Jalili Z. The effect of educational intervention based on the health belief model on improvement of preventive behaviors towards premenstrual syndrome (PMS) among girls of preuniversity in Tehran. Iran J Health Educ Health Promot. 2017;5(3):251-9.

30. Hadiseh F, Mohebbi B, Tol A, Sadeghi R, Nori Jaliani K. The impacts of blended educational intervention program on blood pressure control and promoting $\mathrm{HbA1c}$ among type 2 diabetic patients with hypertension. Razi Journal of Medical Sciences. 2015;22(131):88-96.

31. Babaei sis M RS, Mahmodi $H$, Babazadeh T, moradi F, Mirzaeiyan K,. The Effect of Lifestyle Modification Educational Intervention on Hypertension in Patients with Hypertension.

32. Fathi Y, Moeini B, Bazvand A, Barati M, Roshanaei G. The effectiveness of educational program based on theory of planned behavior on preventing and decreasing tobacco smoking among post-secondary students Journal of Education and Community Health. 2016;3(2):54-61.

33. ghafari $M$ NS, Nori $A$, Khodadost $M$. Impacts of a health belief model-based education program about osteoporosis prevention on junior high school students' physical activity, Kalaleh, Iran, 2012. Jorjani Biomedicine Journal. 2014;1(1):1-9.

34. Reisi M MF, Javadzade $H$, Jalilian F, Mahaki B, Sharifirad GH. Effect of Theory Based Education on Blood Sugar Control in Type-2 Diabetic Patients. Iranian Journal of Endocrinology and Metabolism. 2017;18(6):420-31. 